\title{
Neural stem cells-from quiescence to differentiation and potential clinical uses
}

\section{Alexandra-Elena Dobranici ${ }^{1}$, Sorina Dinescu ${ }^{1,2 \bowtie}$, Marieta Costache ${ }^{1,2}$}

\author{
${ }^{1}$ Department of Biochemistry and Molecular Biology, Faculty of Biology, University of Bucharest, 91-95 Splaiul \\ Independenței, 050095 Bucharest, Romania; ${ }^{2}$ Research Institute of the University of Bucharest, Bucharest, Romania \\ ${ }^{\circledR}$ Correspondence to: Sorina Dinescu, Department of Biochemistry and Molecular Biology, Faculty of Biology, University of \\ Bucharest, 91-95 Splaiul Independentei, 050095 Bucharest, Romania E-mail: sorina.dinescu@bio.unibuc.ro
}

Received: 11 June 2021 / Revised: 17 July 2021 / Accepted: 20 July 2021 / Available online: 30 July 2021

\begin{abstract}
Specialised cells of the brain are generated from a population of multipotent stem cells found in the forming embryo and adult brain after birth, called neural stem cells. They reside in specific niches, usually in a quiescent, non-proliferating state that maintains their reservoir. Neural stem cells are kept inactive by various cues such as direct cell-cell contacts with neighbouring cells or by soluble molecules that trigger intracellular responses. They are activated in response to injuries, physical exercise, or hypoxia condition, through stimulation of signaling pathways that are usually correlated with increased proliferation and survival. Moreover, mature neurons play essential role in regulating the balance between active and quiescent state by realising inhibitory or activating neurotransmitters. Understanding molecular mechanisms underlying neuronal differentiation is of great importance in elucidating pathological conditions of the brain and treating neurodegenerative disorders that until now have no efficient therapies.
\end{abstract}

Keywords: neural stem cells, quiescence, proliferation, neural differentiation

\section{Introduction}

Neural stem cells (NSCs) are multipotent stem cells found in both embryonic and adult brain. Embryonic NSCs' niches are represented by ventricular zone (VZ) and subventricular zone (SVZ), while in the adult brain these cells reside in SVZ and subgranular zone (SGZ) located in the dentate gyrus (DG) (Zhang and Jiao 2015). Stem cell niches are specific microenvironments that influence stem cell activation, self-renewal capacity, proliferation, and differentiation by exposing them to external stimuli. Thus, besides internal regulators, stem cell fate is controlled through direct cell-cell interactions established between cell surface molecules, soluble factors or even mechanical cues provided by the extracellular matrix (ECM) (Solozobova et al., 2012). Embryonic NSCs derive from neuroepithelial cells that later become radial glial cells, losing epithelial characteristics, and gaining astroglial features (Yao et al., 2016). During embryonic development, NSCs undergo symmetric divisions that maintain stem cell pool, and asymmetric divisions that give rise to progenitor cells which will consequently generate specialised cells of the central nervous system. (Zhang and Jiao 2015). In the adult brain, NSCs, like many other adult stem cells, are usually maintained in an inactive state, called quiescence, characterized by the absence of mitotic divisions (Ding et al., 2020). However, NSCs can initiate cell cycle progression as a response to nutrients, physiological stimuli, and physical activity (Fabel and Kempermann 2008; Ding et al., 2020; Urbán et al., 2019). Preserving the balance between quiescence and proliferation is crucial since dysregulation can lead to serious pathologies of the nervous system. Aberrant divisions can give rise to malignant diseases such as glioma or Huntington disease, while impaired differentiation might be engaged in neurodegenerative disorders such as Alzheimer's. However, the exact mechanism underlying these disorders are still debated and under investigation (Steindler et al., 2012; Shen et al., 2019). Unexpectedly, recent investigations found that ablation of NSCs in Alzheimer's disease models can improve cognitive function and synaptic transmission, without affecting amyloid $\beta$ levels (Zhang et al., 2021). Thus, there is need of further studies regarding NSCs' implication in pathologies of the nervous system

\section{Maintenance of quiescent cells}

In normal physiological conditions most NSCs are found in a quiescent state which represents a reversible form of cell-cycle arrest, usually in the G0 or G2 stages of the cell cycle (Otsuki and Brand, 2020). In case of injury or pathological conditions, they can re-enter the cell-cycle, but generate only a few mature neural cells that integrate into existing circuits ( $\mathrm{Li}$ et al., 2010; Wang et al., 2011). 
Interestingly, cells in the G2 phase are the first ones to reactivate in Drosophila melanogaster. However, the choice between G2 or G0 phases seems to be completely invariant (Otsuki and Brand, 2018). Maintenance of quiescence is an active, important process since it avoids exhaustion of the stem cell pool. It is controlled by both extrinsic and intrinsic factors, such as niche components or epigenetic regulators, depending on physiological state and other stimuli (Fabel and Kempermann 2008; Ding et al., 2020). Neighbouring neurons and endothelial cells, establishing direct cell-cell interaction with NSCs, control their quiescent state through membrane-bound proteins, such as ephrinB2, ephrin B3 and Jagged 1 (Ottone et al., 2014; Dong et al., 2019). Additionally, release of diffusing molecules allows quiescence regulation by cells that aren't in close proximity. Distal control of NSCs activity can be mediated by bone morphogenetic proteins (BMPs) (Mira et al., 2010; Marqués-Torrejón et al., 2021), Wingless-related integration site (Wnt) antagonists (Jang et al., 2013; Sun et al., 2015) or neurotrophin 3 (NT-3) (Delgado et al., 2014). Transcriptional analysis revealed that NSCs' quiescence is associated with increased responses to niche signaling, decreased transcriptional and translational activity and the use of glycolysis as the main source of energy (Shin et al., 2015; Llorens-Bobadilla et al., 2015; Dulken et al., 2017; Urbán et al., 2019). Moreover, inactive NSCs are characterized by low epigenetic silencing, including low miRNAs expression (Shi et al., 2010; Massirer et al., 2011). Quiescent NSCs are a heterogenous population, having different degrees of inactivity and ability to activate and regain latency (Otsuki and Brand 2020).

\section{A. Extrinsic regulators in NSCs quiescence}

\section{A.1. Notch signaling}

Notch signaling has an important role in controlling NSCs' quiescence. It is activated by ligands from Delta and Jagged protein families which determine translocation of the Notch intracellular domain (NCID) into de nucleus, where it interferes with recombining binding protein suppressor of hairless (Rbpj) and with coactivator Mastermind-like (Maml). These events lead to expression of hairy and enhancer of split (hes) gene family, Hes1 and Hes5 being antagonists of Neurogenin 2 and Achaete-scute homolog 1 (Ascl1) (ArtavanisTsakonas et al., 1999; Kageyama et al., 2007: Sueda and Kageyama 2020). Conditional knock-out of Rbpj in mice lead to increased neuronal differentiation for a short period of time, followed by reduction of NSCs reservoir and failure of neurogenesis (Imayoshi et al., 2010). There are different types of Notch receptors which are thought to induce distinct cellular responses with Rbpj as a downstream effector. Notch1 receptor seems to be involved in activation and neural differentiation of NSCs (Basak et al., 2012; Herrick et al., 2018). Activation of NSCs might be mediated by induced oscillations in Hes 1 levels, their frequency being the main triggering cue
(Kaise and Kageyama 2021). On the other hand, Notch 2 and 3 receptors are involved in maintaining NSCs' quiescence (Alunni et al., 2013; Kawai et al., 2017; Engler et al., 2018;). In DG, Notch2 signaling was proved to directly target inhibitor of differentiation 4 (id4), up regulating its expression along with hes5. Overexpression of Id4 blocks cell-cyle entry and promotes astrocytic differentiation (Zhang et al., 2019). However, there are contradicting results that present Notch1 role in maintaining NSCs pool and quiescence (Ables et al., 2010; Herrick et al., 2017), or a collaborative action between Notch1 and Notch2 in quiescence and neuronal differentiation (Herrick et al., 2018; Mase et al., 2020). These contrasting discoveries emphasize the need for a better understanding and further studies on Notch receptors in NSCs' quiescence. Besides regulating hes genes, Notch/Rbpj signaling might act by increasing SRY-box transcription factor 2 (Sox2) expression. In Rbpj defective mice, restoring Sox 2 levels had a positive impact on NSCs' pool depletion (Ehm et al., 2010). However, Sox 2 is rather considered to be a stemness marker (Graham et al., 2003; Suh et al., 2007; Favaro et al., 2009; Codega et al., 2014; Than-Trong et al., 2018). Than-Trong et al. (2018) identified Heyl as a downstream effector of Notch3 signaling that indirectly regulates sox2, controlling NSCs' stemness.

\section{A.2 Neurotransmitter regulation}

Signaling through neurotransmitters modulates NSCs' quiescence and activation in both neurogenic niches. Radial glial-like NSCs located in SGZ are maintained quiescent through gamma aminobutyric acid (GABA) released by parvalbumin-positive interneurons. Moreover, at SVZ level, neural progenitor cells have the same effects. NSCs' responses to GABA are mediated through both ionotropic $\mathrm{GABA}_{\mathrm{A}}$ and G-protein coupled metabotropic $\mathrm{GABA}_{\mathrm{B}}$ receptors (Song et al., 2012; Giachino et al., 2014). Further investigations revealed distant control of quiescent NSCs by neurons from medial septum. These cells send depolarizing GABA signals to parvalbumin expressing interneurons, through long projections (Bao et al., 2017). Other distant regulators are Mossy cells, which use one direct and one indirect pathway to induce opposite responses in NSCs. When moderately stimulated, they promote quiescence through commissural projections that activate GABA releasing interneurons. On the other hand, high stimulation led to dominant direct pathway that uses glutamatergic signaling to activate NSCs (Yeh et al., 2018). Treatment with $\mathrm{GABA}_{B}$ receptor antagonist in cerebral ischemic mice improved proliferation of neural stem cell, the amount of immature neurons and neurogenesis, emphasizing the role of GABA in NSCs pool maintenance (Song et al., 2021). Contrariwise, kalinic acid, a glutamate receptor agonist, activate NSCs and stimulate astrocytic differentiation, while high doses led to adoption of reactive astrocyte phenotype (Sierra et al., 2015). Interestingly, NSCs present diazepam binding 
inhibitor that interfere with GABA signaling and promote their proliferation. This mechanism could be an adaptative response to extrinsic stimuli that maintains equilibrium between proliferation and stem cell pool preservation (Dumitru et al., 2017).

\section{A.3 Wnt signaling inhibition}

Wnt ligands represent a family of secreted glycoproteins, rich in cystine, that bind to Frizzled and LRP5/6 receptors (LDL receptor-related proteins 5 or 6). Canonical Wnt signaling involves recruitment of Axin and disheveled (Dvl), event that allows the transfer of $\beta$ catenin intro the nucleus, where it binds to $\mathrm{T}$-cell factor/lymphoid enhancer factor (TCF/LEF) family of transcription factors (MacDonald et al., 2009; Niehrs 2012; Bengoa-Vergniory and Kypta 2015). NSCs in both neurogenic niches are activated by canonical Wnt signaling, promoting self-renewal and proliferation (Lie et al., 2005; Bowman et al., 2013; Qu et al., 2013; Urbán et al., 2019). Therefore, antagonists of Wnt proteins are expected to revert these effects. In mice, Wnt inhibitor Dickkopf-1 (Dkk-1) is responsible of supressing neurogenesis, while its loss led to increased activity of neural progenitor stem cells and glutamatergic differentiation (Seib et al., 2013). In mouse DG, granule neurons secrete Wnt antagonist secreted frizzled-related protein 3 (sFRP3), whose loss activates quiescent NSCs and neuron maturation (Jang et al., 2013). Further analysis revealed that sFRP3 activity is gradually decreased along the septo-temporal axis, resulting into a graded distribution of neurogenesis (Sun et al., 2015). Moreover, Chavali et al., (2018) identified non-canonical Wnt signaling in SVZ, which is involved in NSCs' quiescence. This pathway actions through Rho-GTPase CDC42, promoting NSCs attachment to the niche. During demyelination, switching from non-canonical to canonical Wnt signaling is necessary to achieve proliferation and tissue repair.

\section{A.4 Other extrinsic signals provided by the niche}

Vasculature is an important component of the NSCs' niche, not only for its trophic support, but also for providing signals that influence their fate. NT-3 originating from endothelial cells and choroid plexus capillaries, is delivered to NSCs via vasculature and cerebrospinal fluid, where it induces phosphorylation of nitric oxide synthase. Nitric oxide in turn, acts as a cytostatic factor that promotes quiescence (Delgado et al., 2014). In SVZ, NSCs establish direct cell-cell interactions with endothelial cells, which are mediated by ephrinB2 and Jagged1 proteins, resulting in cell-cycle arrest and induction of quiescence. EphrinB2 diminishes CyclinD expression by attenuating mitogen activated protein kinase (MAPK) signaling, while Jagged1 maintains type B-cell phenotype (Ottone et al., 2014). Glutamatergic neurons in direct contact with NSCs, modulate activation and quiescence by interfering with ephrinB3-ephrinB2 signaling (Dong et al., 2019).

\section{B. Intrinsic regulators in NSCs quiescence}

Recent transcriptomic profiling revealed key role of lysosomal degradation in balancing proteostasis with implications in NSCs' quiescence and activation. Quiescent NSCs present more protein aggregates which accumulate in large lysosomes, while active NSCs have intense proteasome activity. Aging impairs lysosomal functions causing protein aggregates accumulation, thus dampening NSCs activation. On the contrary, stimulation of lysosomal degradation reverts NSCs' ability to activate (Leeman et al., 2018). Ablated lysosomal activity results in exit from quiescent state, conditioned by activation of Notch and epidermal growth factor (EGF) receptors, while activated EGF receptor (EGFR) is degraded at higher rates in dormant NSCs. Moreover, conditional knockout of transcriptional factor EB, a key regulator in lysosomal biogenesis, increases NSCs proliferation in vivo, along with expression of activated EGFR and Notch1 (Kobayashi et al., 2019). However, protein S ablation in mice lead to exit from quiescence accompanied by decreased expression of Notch1, Jagged, Hes1 and Hes5 proteins (Zelentsova et al., 2017). Proteolysis is also involved in returning to quiescence of active NSCs. E3-ubiquitin ligase Huwe1 determines destabilization of Ascl1 which in turn prevents accumulation of cyclin Ds and induces a dormant state of activated NSCs in DG (Urbán et al., 2016).

\section{Neural stem cell activation and proliferation}

Activation and proliferation of NSCs can occur in response to environmental cues such as physical exercise (Dumitru et al., 2017), circadian rhythm (Draijer et al., 2019), or to support physiological needs after tissue damage (Chavali et al., 2018) and neuronal loss (Barkho et al 2011). Similar to quiescence, NSCs' activation and proliferation are coordinated by internal and external stimuli provided by the niche (Otskui and Brand, 2018; Zhang et al., 2020) (Fig.1). Additionally, stimuli such as EGF and basic FGF (bFGF) can manifest collaborative effects with other cues (Arsenijevic et al., 2001; PaezGonzalez et al., 2014; Matsui and Mori, 2018). Soluble molecules released by M2-polarized microglia synergise with bFGF and EGF in maintaining proliferative state of NSCs, emphasizing the role of immunological profile (Matsui and Mori, 2018). A distinct population of choline acetyltransferase (ChAT) positive neurons in SVZ exercises the same effects in combination with FGF (Paez-Gonzalez et al., 2014), enhancing neurogenesis and recovery after stroke (Wang et al., 2017). Also, endothelial cells utilise betacellulin, a member of the EGF family to support proliferation and neurogenesis (Gomez-Gaviro et al., 2012), while leucine-rich repeats and immunoglobulin-like domanins protein 1 prevents exist from quiescence by limiting EGFR signaling activation (Marqués-Torrejón et al., 2021). Stimulation of EGFR signaling induces cell cycle entry of quiescent 
NSCs by activation of phosphoinositide 3-kinase $(\mathrm{PI} 3 \mathrm{~K}) / \mathrm{Akt}$, mitogen-activated protein kinase kinase $(\mathrm{MEK}) /$ extracellular signal-regulated kinases (ERK) and mechanistic target of rapamycin (mTOR) pathways (Cochard et al., 2021). Moreover, absence of EGFR in mice causes impaired NSC expansion and susceptibility to epileptic seizures (Robson et al., 2018). A possible dual role exists for BMP signaling, as it was proved to be involved in both quiescent maintenance (Mira et al., 2010; Marqués-Torrejón et al., 2021) and proliferation (Chen et al., 2019). NSCs' activation can also be dictated by internal regulators such as cell cycle heterogeneity (Otsuki and Brand 2018) or proteostasis modulated by vimentin (Morrow et al., 2020).

\section{A. WNT signaling}

Various cues, such as epigenetic regulators (Wang et al., 2017; Zhang et al., 2018), oxygen levels (Qi et al., 2017), or inorganic salts (Zhang et al., 2019) induce NSCs proliferation through $\mathrm{Wnt} / \beta$-catenin signaling. Orphan nuclear receptor TLX increases Wnt7 expression in NSCs and their proliferative capacity, suggesting an autocrine/paracrine mechanism to control proliferation (Qu et al., 2010). Additionally, Wnt-stimulated glial cells secrete soluble factors that enhance NSCs' proliferation (Yue et al., 2020). Neurotoxins such as paraquat (Zhao et al., 2018) or organic compounds (Tiwari et al., 2015) inhibit NSCs' proliferation by interfering with this pathway. Several micro RNAs that are involved in inhibiting or supressing tumorigenic processes, also control proliferation in NSCs through $\mathrm{Wnt} / \beta$-catenin signaling. MiRNA-21 and 124 overexpression led to increased levels of $\beta$-catenin and its downstream target Cyclin D1 along with decreased expression of glycogen synthase kinase-3 $\beta$ (GSK-3 $\beta$ ) and p21 (Jiao et al., 2018; Zhang et al., 2018). In hypoxic conditions, miR-26a prevents NSCs apoptosis by directly targeting GSK-3 $\beta$ mRNA transcript (Li et al., 2019), while miR-148b inhibits proliferation by interefering with Wnt1 mRNA (Wang et al., 2017). Furthermore, low oxygen levels are important regulators of stemness and proliferation, as NSCs reside in hypoxic niches during embyonic development and in adult brain (Wu et al., 2018). Both adult and foetal NSCs proliferate in low hypoxic conditions dependent of $\mathrm{Wnt} / \beta$-catenin signaling. However, unlike foetal cells, in adult NSCs, Wnt $\beta$ catenin pathway activity occurs in response to hypoxiainducible factor-1 $\alpha$ (HIF-1 $\alpha$ ) (Braunschweig et al., 2015; Qi et al., 2017). In normoxic conditions HIF-1 $\alpha$ response is impaired due to its prolyl hydroxylases mediated degradation (Wu et al., 2018). Proliferation dependent on Wnt/ $\beta$-catenin signaling is dysregulated due to heme oxygenase activity, a common characteristic in Parkinson and Alzheimer's diseases (Si et al., 2020). Gisenoside 20 (S)-prtopanaxadiol and oleanoic acid enhance NSCs' proliferation through Wnt/ $\beta$-catenin activity and ameliorate cognitive deficits in mice (Zhang et al., 2018; Lin et al., 2020; Lin et al., 2021).

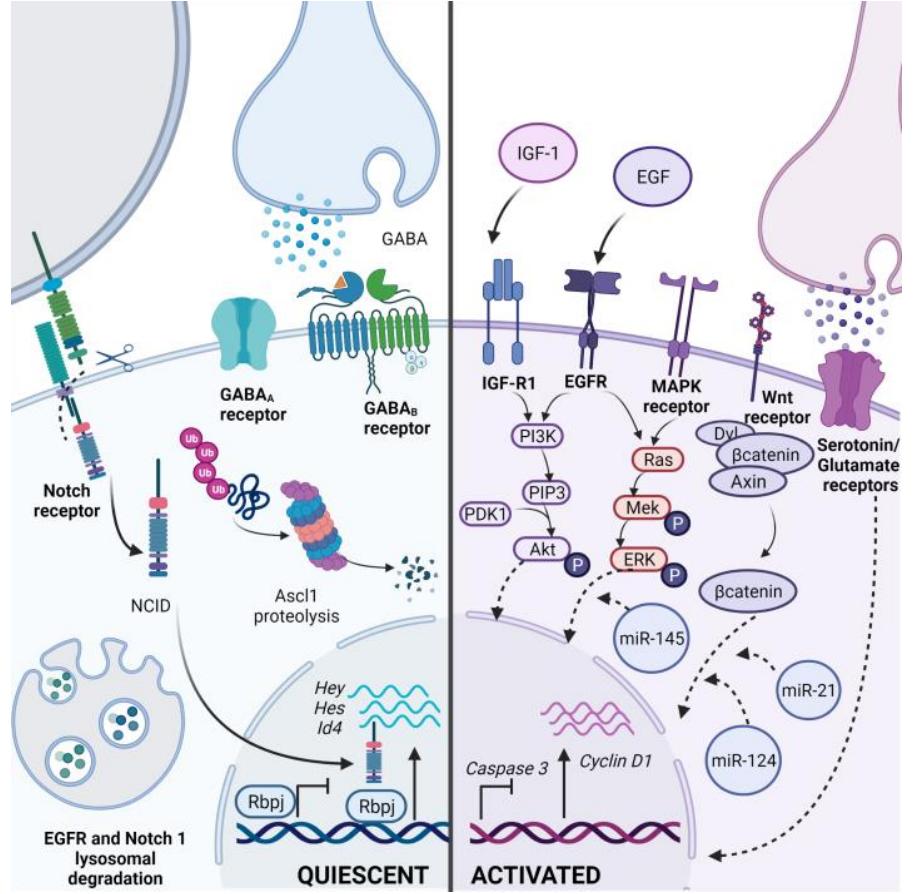

Fig.1. External and internal stimuli controlling NSCs' quiescent state and activation. NSCs are exposed to various cues that dictate their choice between quiescence and activation. External regulators provided by the niche could be represented by direct cell-cell contacts, soluble factors or even neurotransmitters. These stimuli can trigger intracellular signaling pathways with further repression or activation of transcription. The figure was created in BioRender.

\section{B. MAPK/ERK and AKT signaling}

MAPK and Akt are both signaling pathways associated with cell proliferation and migration, their aberrant expression often leading to malignant pathologies (McCubrey et al., 2007). MAPK signaling consists of four different cascades, depending on their downstream MAPK proteins, which respond to mitogens, growth factors and other external stimuli. Three of them are mediated by ERK1/2, p38-MAPK and Jun aminoterminal kinases (JNK1/2/3) and considered conventional pathways, while the fourth one relies on ERK5 ( $\mathrm{Lu}$ and $\mathrm{Xu}$ 2006; Sun et al., 2015). Akt signaling occurs through activation of cytokine receptors, tyrosine kinase receptors, or $\mathrm{G}$ protein coupled receptors. It involves activation of $\mathrm{PI} 3 \mathrm{~K}$ with further production of phosphatidylinositol3,4,5-triphosphat (PIP3) that recruits 3-phospho-inositide-dependent protein kinase 1 (PDK1). PDK1 phosphorylates Akt proteins, involved in cell growth and survival (Hers et al., 2011). PI3K/Akt signaling can be activated in response to different cues such as reactive oxygen species (ROS) (Le Belle et al., 2011), chaperone proteins (Huang and Wang 2018) or even phytochemicals (Lu et al., 2020; Zhou et al., 2020) to promote NSCs' proliferation. In low hypoxic conditions, niche components secrete vascular endothelial growth factor (VEGF) or brain derived neurotrophic factor (BDNF) that rise PI3K, Akt and JNK 
levels in NSCs (Cai et al., 2014). Moreover, after oxygen-glucose deprivation, glucose-regulated protein 78 exercises anti-apoptotic and proliferative effects through PI3K/Akt and ERK1/2 pathways (Liu et al, 2018). Phytochemicals, such as astragalosides (Chen et al., 2019; Sun et al., 2020) and musk ketone (Zhou et al., 2020), that were known for their beneficial post-stroke effects, decrease apoptosis and enhance proliferation by regulating EGFR/MAPK and PI3K/Akt signaling. Other study identified miR-145 as an important regulator of NSCs' function after ischemia through MAPK pathway, that leads to decreased levels of Cleaved-caspase 3 and increased levels of Cyclin D1. Moreover, overexpression of miR-145 improved walking ability, spatial learning and memory in mice (Xue et al., 2019).

\section{Insulin pathway}

Insulin is an important mediator in the brain and exercises its role in cell growth, autophagy, cognitive and mitochondrial function through insulin receptors (IRs) that activate PI3K/Akt/GSK-3 $\beta$ signaling cascade. Dysfunctional insulin and PI3K/Akt signaling can lead to accumulation of neurofibrillary tangles and amyloid- $\beta$, which are characteristic to Alzheimer's disease (Gabbouj et al., 2019; Akhtar et al., 2020). Early studies have proved the participation of insulin-like growth factors (IGFs) in neural progenitors' cell cycle regulation and proliferation (Lichtenwalner et al., 2001; Aberg et al., 2003; Bracko et al., 2012), as well as its role in NSCs' expansion, survival, and proliferation (Burns and Hassan 2001; Ziegler et al., 2012; Ziegler et al., 2014; Ziegler et al., 2015). IGF-1 is necessary for EGF, and bFGF mediated proliferation and maintenance of NSCs (Arsenijevic et al., 2001). Additionally, co-signaling through IGF-1 and EGF receptors led to enhanced cyclin D1, phosphorylated histone 3 and retinoblastoma (RB) expression, along with increased neural progenitors' proliferation after brain injury (Alagappan et al., 2014). NSCs exposure to insulin resulted in activation of insulin receptor substrate 2 and higher activity of G1-pahse cyclin-dependent kinase 4 with increased proliferation and neuron maturation (Chirivella et al., 2017). In $D$. melanogaster, heat shock protein 83 (Hsp83) acts as an internal regulator of NSCs' exit from quiescence and reactivation by associating with co-chaperone $\mathrm{Cdc} 37$ and IR, triggering PI3K/Akt signaling (Huang and Wang 2018). NSCs are maintained quiescent by protein phosphatase 2 A of the Striatin-interacting phosphatase and kinase complex, which prevent premature activation of IR and PI3K/Akt signaling. Oppositely, activity of MOB family member 4 along with connector of kinase to AP-1 belonging to the same complex reverts these effects and induces reactivation (Gil-Ranedo et al., 2019). A concerning aspect is that insulin-like growth factor binding protein 2 (IGFBP2) expression is often enhanced in glioblastoma and is corelated with cancer progression, poor survival, and recurrence (Doetsch et al., 1999; Sallinen et al., 2000; Elmlinger et al., 2001; Lin et al.,
2009; Moore et al., 2009; Shen et al., 2019). Shen et al., (2019) identified that IGFBP2 promotes proliferation, while inhibiting neuronal and astrocytic differentiation of NSCs, regulating cell cycle genes similar as in glioblastoma cells. Thus, low activity of insulin pathway poses the risk of developing Alzheimer's disease, while aberrant functioning might increase chances of aggressive malignant processes.

\section{Neurotransmitters}

Neural cells utilise neurotransmitters such as GABA (Yeh et al., 2018), glutamate (Liu et al., 2015), acetylcholine (Paez-Gonzales et al., 2014) or serotonin (Tong et al., 2014) to exercise control on NSCs' fate. While GABA acts predominantly as an inhibitor of proliferation and inductor of quiescence, glutamate stimulates cell cycle progression (Moss and Toni, 2013; Yeh et al., 2018). On the other hand, Shrm4 activates $\mathrm{GABA}_{\mathrm{B} 1}$ signaling that further leads to upregulation of anti-apoptotic and mitogen proteins' expression, along with downregulation of pro-apoptotic ones (Tian et al., 2020). Glutamate exercises its proliferative effects on NSCs and neural progenitors by increasing levels of VEGF and cyclin D1 (Liu et al., 2015), along with $\alpha$ amino-3-hydroxy-5-methyl-4-isoxazolepropionic acid (AMPA) receptor activation and calcium uptake (Song et al., 2017). Moreover, studies conducted on metabotropic glutamate receptors revealed them to be important targets in regulating NSCs' proliferation (Erichsen et al., 2015; Dindler et al., 2018).

Serotonin is another regulator of NSCs' proliferation and expansion, as they express serotonergic receptors $2 \mathrm{C}$ and 5A. In V-SVZ, serotonergic neurons from dorsal and median raphe emit axonal projections that activate NSCs' proliferation and neurogenesis (Tong et al., 2014). In adult mouse, activation of serotonin receptor $2 \mathrm{~A}$ promotes basal progenitor proliferation, through ERK signaling (Xing et al., 2020). Also, N-acetyl serotonin prevents oxidative stress in NPCs and counteracts proliferative and migratory capacity impairments by increasing activity of PI3K/Akt/cAMP pathway ( $\mathrm{Li}$ et al., 2019). However, in zebrafish, inflammatory processes associated with Alzheimer's disease impair tryptophan metabolism in serotonergic neurons, inhibiting NSCs' proliferation and neurogenesis. Thus, impaired serotonin production acts indirectly on NSCs, stimulating BDNF release and further activation of nerve growth factor (NGF) receptor signaling (Bhattarai et al., 2020). These results indicate a context-dependent role of serotonergic control in NSCs' niche.

\section{Neural stem cells' paths of differentiation and lineage specific markers}

It was observed that NSCs can generate new types of neural cells, astrocytes and oligodendrocytes when implanted at brain level (Kang et al., 2014). In order to give rise to specialised cells of the brain, NSCs go 
through multiple differentiation stages, characterized by specific markers. However, the complete mechanisms underlying cell lineage specification in vivo are not fully understood (Beattie and Hippenmeyer 2017). A proposed scheme of differentiation and markers for each stage are represented in Fig. 2, along with key regulators of specification. NSCs in the adult brain are also called radial-glial cells, considered to be a subset of astrocytes that are set aside during embryogenesis to become NSCs residing at SVZ and SGZ level (Zhao and Moore 2018). Radial glial cells in the DG express markers common to astrocytes, stems cells and NSCs from developing embryo, such as Nestin, Sox 2 and glial fibrillary acidic protein (GFAP). After division, they generate intermediate progenitor cells (IPC) positive for T-box brain protein 2 (Tbr2). These cells are lineage restricted and thus, experience limited rounds of division. (Hodge et al., 2008; Bonaguidi et al., 2011; Berg et al., 2015; Berg et al., 2018).

\section{A. Neuronal stages of differentiation and markers}

Intermediate progenitor cells (IPC) differentiate to give rise to immature and further mature neurons. Besides Tbr2, they also express GFAP, Achaete-scute complex homolog-1 (Ascl1), minichromosome maintenance protein 2 (MCM2) and forkhead box O3 (FoxO3) at early stages. However, towards differentiation into more mature neurons, markers such as doublecortin, NeuN, Calretinin or RE1-silencing transcription factor (REST) are beginning to be expressed (Zhang and Jiao 2015). Giving the fact that NSCs generate multiple specialised types of neurons, each specification is associated with a unique profile of markers. These markers are mostly involved in neurotransmitters' metabolism and transport, besides mature neurons-associated proteins. When discussing dopaminergic differentiation, some of the most investigated markers are orphan nuclear receptor (Nurr1) necessary for neuronal lineage specification, tyrosine hydroxylase involved $(\mathrm{TH})$ in dopamine biogenesis and dopamine transporter (DAT) (Wagner et al., 1999; Sagal et al., 2014; Tan et al., 2014; Lee et al., 2016a; Lee at al., 2016b). On the other hand, GABAergic neurons highly express GABA, Calbidin 1 (CALB) and B-cell lymphoma/leukemia 11B (Bcl11B) and glutamate decarboxylase (GAD) isoforms 65 and 67 (Zhao et al., 2013; Abeysinghe et al., 2015; Lin et al., 2015; Nikouei et al., 2016). Glutamatergic differentiation is marked by expression of glutamate receptor 1 (GluR1) and vesicular glutamate transporter 1 and 2 (VGLUT1/2) (Schuurmans et al., 2004; Jeon et al., 2014). Serotonergic neurons are characterized by increased expression of tryptophan hydroxylase (TPH), aromatic aminoacid decarboxylase (AADC), vesicular monoamine transporter (VMAT), Hrtla and GATA-binding factor (GATA) 2 and 3 transcription factors. Moreover, mature neurons express functional serotonin transporter (SERT) (Salli et al., 2004; Ren-Patterson et al., 2005; Cao et al., 2017). Finally, motoneurons express choline acetyltransferase
(ChAT) enzyme involved in acetylcholine synthesis, insulin gene enhancer protein $1 / 2$ (ISL-1/2) and $\mathrm{Hb} 9$ (O'Brien et al., 2015; Jordan et al., 2008; Natarajan et al., 2014).

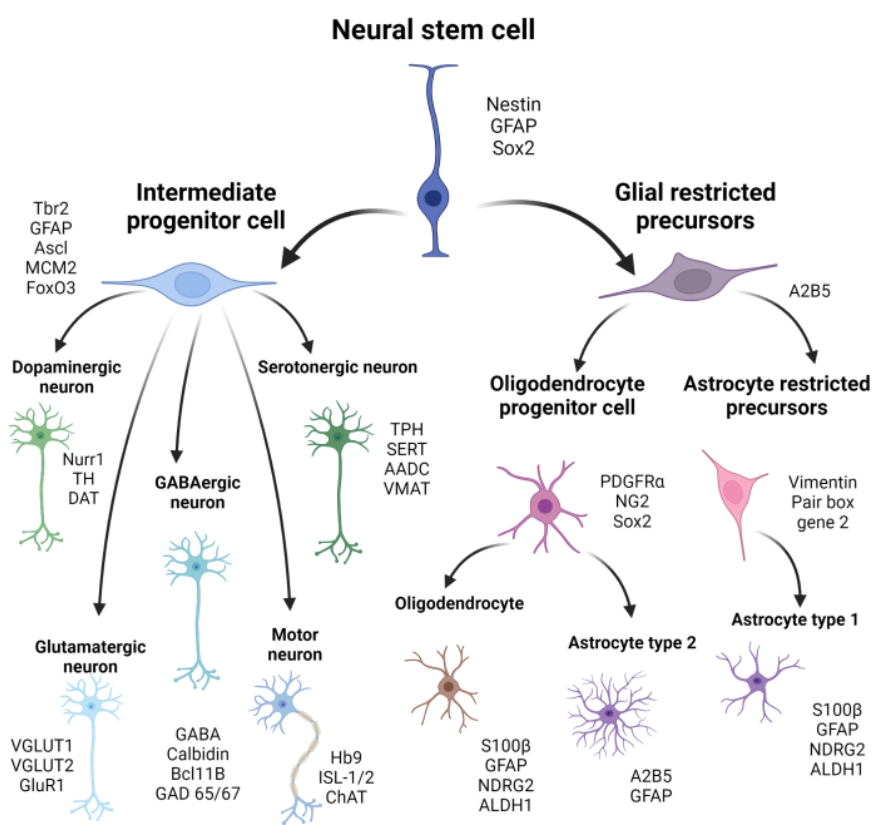

Fig.2. NSC' paths of differentiation and specific markers expressed at each stage. The figure was created in BioRender.

\section{B. Glial stages of differentiation and markers}

Radial glial cells/NSCs also generate astrocytes and oligodendrocytes. However, existing data is not clear about the identity of possible intermediate precursor that further differentiate into these specialized cells, and it needs more investigations. A subtype of precursors called glial restricted precursor cells are able to differentiate into oligodendrocytes and type 1 and 2 astrocytes. Type 1 astrocytes could derive from astrocyte restricted precursors, while type 2 astrocytes and oligodendrocytes could be derived from oligodendrocytes precursors (Martins-Macedo et al., 2021). Regarding their specific markers, glial restricted progenitors express A2B5 antibody (Campanelli et al., 2008; Martins-Macedo et al., 2021). Upon further differentiation into oligodendrocytes precursor, these cell express platelet-derived growth factor receptor $\alpha(\mathrm{PDGFR} \alpha)$, neural/glial antigen 2 (NG2) and Sox2 (Lee et al., 2000; Rowitch et al., 2002; Campanelli et al., 2008). Oligodendrocytes are characterized by several markers such as myelin basic protein (MBP), NG-2 or oligodendrocyte-specific protein (OP) (Michalski et al., 2018), while astrocytes type 2 are positive for A2B5 and GFAP (Raff et al., 1993). Astrocyte precursors can be identified through a specific profile of markers that includes pair box gene 2 and vimentin without expression of GFAP and S100 (Mi and Barres 1999; Martins-Macedo et al., 2021). Astrocytes on the other hand express S100 $\beta$ along with GFAP, NDRG2 
and aldehyde dehydrogenase 1 (ALDH1) (Cahoy et al.,2008; Zhang et al., 2019).

\section{Neural differentiation}

A schematic representation of possible neural differentiation pathways of NSC, along with necessary inducers is provided in Fig.3.

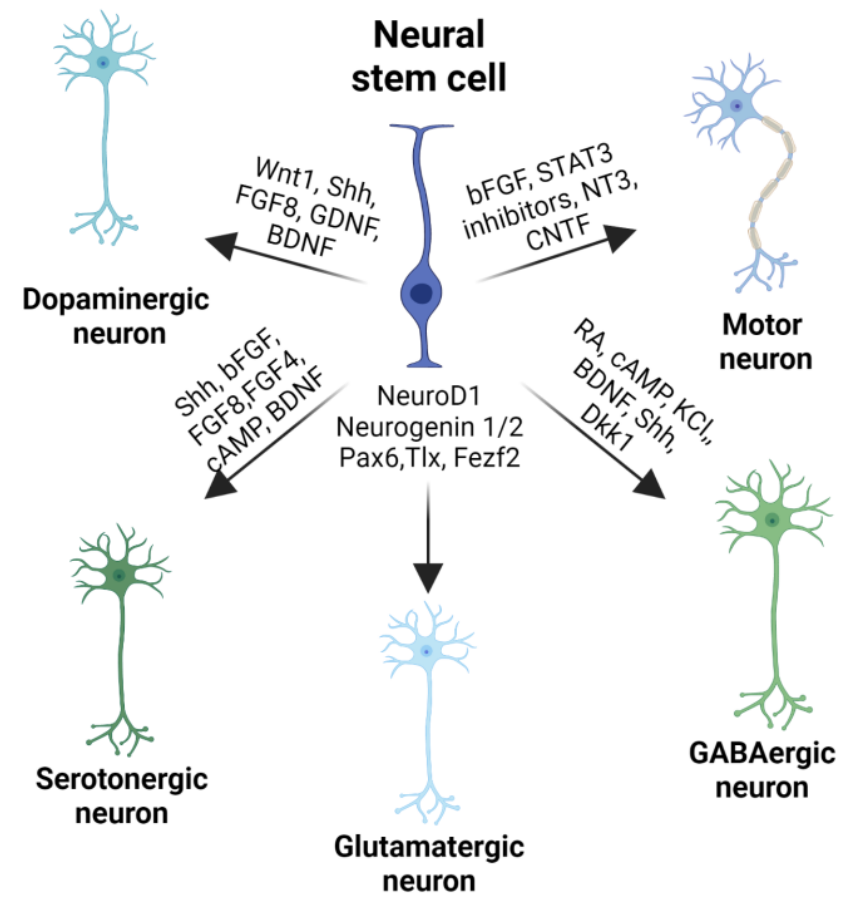

Fig.3. Neural differentiation of NSCs and inducers necessary for lineage specification. The figure was created in BioRender.

\section{A. Motor neurons}

Motor differentiation of NSCs holds great promise in the treatment of neurodegenerative pathologies such as Machado-Joseph disease (Mendonça et al., 2015) or amyotrophic lateral sclerosis (ALS) (O'Brien et al., 2015). Most studies utilise other cell types, such as astrocytes (Shao et al., 2011) and pluripotent stem cells (Yun et al., 2015; Jha et al., 2015) to obtain human NSCs and further differentiate them intro motoneurons. When NSCs originate from other adult multipotent stem cells, like human adipose-derived stem cells, it is considered transdifferentiation as it results in obtaining cells with another germ layer origin (Darvishi et al., 2017; Darabi et al., 2017).

Human foetal NSCs could be differentiated into $\mathrm{Hb}^{+}$and $\mathrm{ChAT}^{+}$motoneurons upon priming with bFGF for 4 days, identifying its role not only for proliferation, but also in plasticity. Thus, higher concentrations of FGF have mitogenic effects, whereas lower concentrations support neurogenesis (Jordan et al., 2009). This is aquired by temporal control of $\mathrm{PI} 3 \mathrm{~K} / \mathrm{Akt} / \mathrm{GSK}-3 \beta$ pathway that maintains low levels of phosphorylated Akt (p-Akt) in favour of GSK-3 $\beta$ activation both in vitro and in vivo
(Ojeda et al., 2011). Signal transducer and activator of transcription 3 (STAT3) inhibitor synergise with bFGF in promoting motoneuron phenotype and diminishing levels of astrocytic marker GFAP, by inhibiting nuclear translocation of STAT3 (Natarajan et al., 2014). Other molecules used to differentiate NSCs, regardless of their origin, into motoneurons are retinoic acid (RA), sonic hedgehog (Shh) and purmorphamine. These factors induce immature cells or motor neuron progenitors which require the presence of BDNF, glial-derived neurotrophic factor (GDNF), NT-3 and ciliary neurotrophic factor (CNTF) for survival and maturation (Shao et al., 2011; Jha et al., 2015; Yun et al., 2015; Darvishi et al., 2017). Besides soluble factors, functionalized biomaterials that mimic nervous tissue could be utilised to induce better yields, as they provide mechanical and biochemical cues necessary for adherence and allow proper release of differentiation inducers (Binan et al., 2014; Yun et al., 2015). In vivo, it was observed that Reelin/Disabled pathway is necessary for motoneuron differentiation of NSCs and neural progenitors' grafts after transplantation in mice (Arimitsu et al., 2019).

\section{B. Dopaminergic neurons}

Impaired dopaminergic functioning is one of the main causes underlying neurological pathologies such as Parkinson's disease, drug and alcohol addiction or schizophrenia (Daadi 2019). During embryogenesis, Wnt ligands, FGF-8 and Shh are the main regulators of dopaminergic differentiation. Wnt ligands, especially Wnt1, block GABAergic or serotonergic transcriptional programs by repression of $\mathrm{Nkx} 2.2$ and by upregulating Orthodenticle homeobox 2 (Otx2) expression, while FGF8 and Shh are important inducers of dopaminergic differentiation (Ye et al., 1998; Rössler et al., 2010). Rössler et al., (2010) utilised the same cocktail of factors on non-mesencephalic NSCs obtaining few dopaminergic precursors. Adding an inhibitor of histone deacetylase resulted in higher yields and more mature dopaminergic neurons, emphasizing the importance of epigenetic regulators. This treatment led to elevated expression of dopaminergic factors like Otx2 and Msh homeobox 1 (Msx1) along with tyrosine hydroxylase and pituitary homeobox 3 (Pitx3) (Rössler et al., 2010). Other studies also utilised B27, GDNF and BDNF to induce dopaminergic differentiation (Alizadeh et al., 2017; Nakaji-Hirabayashi et al., 2019; Daadi 2019). An important role is attributed to p70 ribosomal S6 kinase (S6K), a downstream effector of $\mathrm{PI} 3 \mathrm{~K} / \mathrm{Akt} / \mathrm{mTOR}$ signaling that is activated in response to insulin in dopaminergic neurons (Fang et al., 2007). S6K promotes dopaminergic differentiation dependent on insulin concentrations both in vivo and in vitro (Lee et al., 2016a). Contrariwise, inhibition of phosphatase and tension homolog (PTEN), which is a PI3K/Akt inhibitor, led to increased proliferation and decreased dopaminergic differentiation of NSCs, while expression of PTEN led to increased S6K activity by supressing ERK pathway. A 
possible explanation of these events is that PTEN signaling exercises a stronger inhibitory effect on ERK pathway which is responsible of supressing phosphorylation of S6K (Lee et al., 2016b).

Early studies demonstrated that the orphan nuclear receptor Nurr1 is necessary for dopaminergic differentiation (Wagner et al., 1999) and that it synergises with Neurogenin 2 in neural progenitor cells to generate mature dopaminergic neurons (Andersson et al., 2007). Single use of Nurr1 was also proved to be incompletely efficient in generating morphologically and phenotypically matured dopaminergic neurons. Tan et al., (2011) identified member of the POU domain family of transcription factor, Brn4, to be necessary for maturation. Moreover, it induces maturation in TH-transfected NSCs by triggering expression of GDNF along with its receptors GFR $\alpha-1$ and Ret (Tan et al., 2014).

\section{Glutamatergic neurons}

In DG, neurodifferentiation of glutamatergic granule cells requires expression of neuroDl for cell-survival and maturation, which is under transcriptional repression control of Sox2. In addition, activation of neuroD1 is mediated by Wnt/ $\beta$-catenin pathway (Liu et al., 2000; Kuwabara et al., 2009; Hodge et al., 2012). Azim et al., (2014) found that Wnt-mediated signaling specifically promotes glutamatergic specification of progenitors in dorsal SVZ. Other transcriptional regulators are Neurogenin 1 and 2, which inhibits GABAergic differentiation, while promoting glutamatergic phenotype in early-born neurons. On the other hand, later-born neurons require a synergic interaction between paired box 6 (Pax6) and orphan nuclear receptor Tlx for specification (Schuurmans et al., 2004). Fragile X mental retardation protein (FMRP), whose mutation is responsible of fragile $\mathrm{X}$ syndrome, acts as translational repressor of NeuroD1 that impairs glutamatergic differentiation. Treatment with valproic acid inverts effects of overexpressing FMRP (Jeon et al., 2014). Moreover, in rats, prenatal exposure to ethanol led to aberrant differentiation of glutamatergic neurons and decreased expression of GABAergic ones. These effects were associated with increased levels of NeuroD, Neurogenin2, Pax6 and postsynaptic density protein-95 (PSD-95) (Kim et al., 2010). Exposure of hippocampal precursors to soluble neural cell adhesion molecule (NCAM) promoted glutamatergic phenotype and upregulated neuroD and neurogenin1, emphasizing the modulatory role of extracellular matrix. Besides transcription factors, increased levels of p-MAPK, GluR1, NR1 and Calcium/calmodulin-dependent protein kinase type II were observed along with decreased level of p-STAT3 (Shin et al., 2002) Furthermore, ectopic expression of fez family of zinc finger 2 (fezf 2 ) induces glutamatergic neurons from GABAergic committed progenitors (Rouaux and Arlotta 2010). In vivo, overexpression of fezf 2 is sufficient to promote differentiation of NSCs from SVZ, preferentially adopting GABAergic path, to convert into glutamatergic neurons (Zuccotti et al., 2014).

\section{GABAergic neurons}

GABAergic differentiation from NSCs can be obtained by blocking Hes1 expression through antisense oligonucleotide along with cultivation in the presence of B27, RA, and dibutyryl cyclic adenosine monophosphate (cAMP) in vitro. This strategy leads to BrdU positive cells that also express GABA and ameliorate seizures and epileptiform discharges in rats (Kabos et al., 2002; Xu et al., 2019). Another approach uses sequential treatment with RA and potassium chloride $(\mathrm{KCl})$ to generate GABA secreting neurons which maintains their phenotype in a Huntington's disease model in vivo. RA treatment induced neuronal differentiation, while $\mathrm{KCl}$ was responsible of the acquired GABAergic phenotype, maturation, and decreased proliferation (Bosch et al., 2004). However, stimulation with BDNF and B27, seems to induce better yields in acquiring GABAergic phenotype than treatment with NGF or RA-KCl (Silva et al., 2009). Moreover, differentiation of human NSCs from SVZ with only BDNF induced GABAergic neurons that improved recovery after ischemic stroke in rats (Abeysinghe et al., 2015). Results from a recent study established that homeobox-containing transcription factor, Engrailed 2, is necessary in GABAergic differentiation as it modulates BDNF signaling (Boschian et al., 2018). A three-step protocol that sequentially combined BDNF with Shh and Dkk-1, along with valproic acid and $\rho$-associated protein kinase inhibitor $Y$ 27632, obtained neurons with increased expression of map2, calb1, darpp, bcl11b and arpp21 genes. Dkk-1 and Shh act collaboratively to promote transition to ventral telencephalic neuron phenotype. Notably, neural differentiation also relied on insulin or IGF-1 stimulation (Lin et al., 2015). Other important regulators promoting transition to GABAergic phenotypes are neurotransmitters (Samarasinghe et al., 2014) and calcium-mediated signaling, (Ciccolini et a., 2003), as well as mechanical cues provided by cell-adhesion molecules (Silva et al., 2009). For example, L1 cell adhesion molecule promotes GABAergic differentiation in detriment of adopting cholinergic differentiation path (Dihné et al., 2003).

\section{E. Serotonergic neurons}

Even though dysfunction of the serotonergic system is involved in neuropsychiatric disorders, there are a few studies investigating differentiation of serotonin producing neurons (Jansch et al., 2021). It seems that Shh is an important regulator of serotonergic regulation during both vertebrate neural specification (Hynes and Rosenthal 1999) and differentiation from ES-derived neural progenitors in vitro (Salli et al., 2004). Besides, Shh, Salli et al. (2004) used bFGF to obtain TPH, serotonin and SERT positive cells. However, this study did not include evaluation of SERT-binding site and 5 
hydroxytriptamine (5-HT) transporter (Ren-Patterson et al., 2005). Embryonic neural progenitors, differentiated into sertonergic-like phenotype after stimulation with Shh, bFGF and FGF-8, manifested good function of SERT activity and 5-HT uptake. Moreover, implantation of these cells into SERT-lacking mice led to increased expression of SERT protein (Ren-Patterson et al., 2005). Riaz et al., (2004) induced serotonergic differentiation in human foetal neural progenitors with the aid of serotonin, FGF-1, BDNF and forskolin. Additionally, NSCs and neural progenitors obtained from induced pluripotent stem cells (iPSCs), could be differentiated into serotonergic neurons after Shh stimulation with further presence of FGF-4, GDNF, BDNF and cAMP (Lu et al., 2016; Jansch et al., 2021). Ascl1 might also contribute to serotonergic differentiation, since a neurogenin family member, that usually directs glutamatergic phenotype, inhibits this type of specification by Hes-mediated repression of Ascl transcription. (Carcagno et al., 2014). Another inhibitor is interleukin $1 \beta$ which is associated with decreased levels of Bcl-2 and pERK (Zhang et al., 2013).

\section{Clinical applications of NSCs}

Given NSCs' multiple possibilities of differentiation, their therapeutic potential was investigated in many pathologies of the nervous system, such as traumatic brain injury (Hu et al., 2020), epilepsy (Maisano et al., 2012), Huntington's disease (Kim et al., 2020) or spinal cord lesions (Hwang et al., 2016). However, an increased interest was manifested for neurodegenerative pathologies, such as Alzheimer's and Parkinson's disease or ALS.

\section{Alzheimer's disease}

According to Alzheimer's Association (2016) this pathology is the most common degenerative disorder in the US where it affects over 5 million people, being associated with loss of cholinergic neurons and synapses (Cattaneo and Calissano, 2012; Zhu et al., 2020). Zhang et al. (2019) implanted NSCs derived from pluripotent stem cells into the hippocampus of Alzheimer's suffering mice, observing efficient differentiation, long-term survival of the newly produced neurons and integration into synaptic circuits. In addition to that, NSCs' transplant improved cognitive abilities. Transplantation of NSCs in Alzheimer's model also leads to metabolic changes by increasing levels of $\mathrm{N}$-acetylasparatate and glutamate, along with enhanced levels of PSD-95, which can be corelated with synaptogenesis (Zhang et al., 2017). Comparable results were obtained in a recent study by Zhu et al., (2020) along with improvement of learning and memory.

\section{Parkinson's disease}

Parkinson's disease involves loss of mesodiencephalic dopaminergic neurons from Substantia nigra that further leads to motor dysfunctions. For this matter, cell replacement therapy could represent an efficient solution for the disruption of the dopaminergic signaling in the brain (Ramos-Moreno et al., 2012). In patients suffering from Parkinson's disease, NSCs show modified transcriptomic and proteomic profiles for genes and proteins participating in mitochondrial function, metabolism, and cytoskeleton organization. Also, they transit into a primed-quiescent, proliferative state (Donega et al., 2019). Implantation of dopaminergic neurons derived from NSCs, not only reduced motor dysfunction in rats, but also improved drug response and cognitive performance, along with enhanced survival and maturation (Ramos-Moreno et al., 2012). These neurons are capable of dopamine release after excitation, have good tyrosine hydroxylase activity and present reduced asymmetric rotation specific to Parkinson's disease (Kang et al., 2014).

\section{Amyotrophic lateral sclerosis}

Amyotrophic lateral sclerosis represents an incurable neurodegenerative disease affecting motoneurons from the primary cortex, brainstem and spinal cord. A phase I clinical study used foetal human NSCs to assess their safety and efficacy after transplantation to ALS suffering patients. NSCs therapy did not increase disease progression and led to improvements that lasted up to 7 months. Giving the fact that only 6 patients were included in this study and the conclusions were promising, there is a need for further investigation on larger groups (Mazzini et al., 2015). It was observed that during NSCs' differentiation into motoneurons, mitochondrial biogenesis is increased, while glycolytic flux is decreased. These results could therefore serve for a better understanding of ALS development that involves impaired mitobiogenesis (O’Brien et al., 2015).

\section{Conclusions}

Neural stem cells represent a heterogenous population of cells residing in two distinct niches at brain level, which further dictate their fate through various mechanical, biochemical, and epigenetic regulators that collaboratively work together in preserving tissue homeostasis. NSCs' fate can be influenced not only by local factors, but also by cells located outside their niche, as well as by cues outside the body such as physical exercise or physiological factors, many of them having specific, contextual effects. Even though there are a lot of studies trying to elucidate the complex mechanism underlying NSCs' fate, there are still unanswered questions and intricacies. Thus, integrative analysis, provided by multi-omics approaches, could serve for a better insight of the relationships existing between different regulators. Nevertheless, NSCs have great potential in treating neurodegenerative disorders, being a huge resource of possible therapeutic strategies. 


\section{Acknowledgments}

This work was supported by a grant of the Romanian Ministry of Education and Research, CNCS-UEFISCDI, project number PN-III-P1-1.1-TE-2019-1191 (197TE/2021), within PNCDI III.

CThe Author(s) 2021

Open Access This article is distributed under the terms of the Creative Commons Attribution 4.0 International License (http://creativecommons.org/licenses/by/4.0/) which permits unrestricted use, distribution, and reproduction in any medium, provided you give appropriate credit to the original author(s) and the source, provide a link to the Creative Commons license, and indicate if changes were made.

\section{References}

Aberg M.A.I., Aberg N.D., Palmer T.D., Alborn A.M., Carlsson-Skwirut C., Bang P., Rosengren L.E., Olsson T., Gage F.H., Eriksson P.S. 2003. IGF-I has a direct proliferative effect in adult hippocampal progenitor cells. Mol. Cell. Neurosci. 24, 23-40.

Abeysinghe H.C.S., Bokhari L., Quigley A., Choolani M., Chan J., Dusting G.J., Crook J.M., Kobayashi N. R., Roulston C.L. 2015. Pre-differentiation of human neural stem cells into GABAergic neurons prior to transplant results in greater repopulation of the damaged brain and accelerates functional recovery after transient ischemic stroke. Stem Cell. Res. Ther. 6, 186. https://doi.org/10.1186/s13287-015-0175-1

Ables J.L., Decarolis N.A., Johnson M.A., Rivera P.D., Gao Z., Cooper D.C., Radtke F., Hsieh J., Eisch A.J. 2010. Notch1 is required for maintenance of the reservoir of adult hippocampal stem cells. J. Neurosci. 30, 10484-10492.

Akhtar A., Sah S.P. 2020. Insulin signaling pathway and related molecules: Role in neurodegeneration and Alzheimer's disease. Neurochem. Int. 135, 104707. https://doi.org/10.1016/j.neuint.2020.104707

Alagappan D., Ziegler A.N., Chidambaram S., Min J., Wood T.L., Levison S.W. 2014. Insulin-like growth factor receptor signaling is necessary for epidermal growth factor mediated proliferation of SVZ neural precursors in vitro following neonatal hypoxiaischemia. Front. Neurosci. 5, 79. https://doi.org/10.3389/fneur.2014.00079

Alizadeh R., Hassanzadeh G., Joghataei M.T., Soleimani M., Moradi F., Mohammadpour S., Ghorbani J., Safavi A., Sarbishegi M., Pirhajati Mahabadi V., Alizadeh L., Hadjighassem M. 2017. In vitro differentiation of neural stem cells derived from human olfactory bulb into dopaminergic-like neurons. Eur. J. Neurosci. 45, 773-784.

Alunni A., Krecsmarik M., Bosco A., Galant S., Pan L., Moens C.B., Bally-Cuif L. 2013. Notch3 signaling gates cell cycle entry and limits neural stem cell amplification in the adult pallium. Development. 140, 3335-3347.

Andersson E.K.I., Irvin D.K., Ahlsiö J., Parmar M. 2007. Ngn2 and Nurr1 act in synergy to induce midbrain dopaminergic neurons from expanded neural stem and progenitor cells. Exp. Cell Res. 313, 1172-1180.

Arimitsu N., Takai K., Fujiwara N., Shimizu J., Ueda Y., Wakisaka S., Hirotsu C., Murayama M.A., Suzuki T., Suzuki N. 2019. Roles of Reelin/Disabled1 pathway on functional recovery of hemiplegic mice after neural cell transplantation; Reelin promotes migration toward motor cortex and maturation to motoneurons of neural grafts. Exp. Neurol. 320, 112970. https://doi.org/10.1016/j.expneurol.2019.112970

Arsenijevic Y., Weiss S., Schneider B., Aebischer P. 2001. Insulin-like growth factor-I is necessary for neural stem cell proliferation and demonstrates distinct actions of epidermal growth factor and fibroblast growth factor-2. J. Neurosci. 21, $7194-$ 7202.

Artavanis-Tsakonas S., Rand M.D., Lake R.J. 1999. Notch signaling: cell fate control and signal integration in development. Science 284, 770-776.

Azim K., Fischer B., Hurtado-Chong A., Draganova K., Cantù C., Zemke M., Sommer L., Butt A., Raineteau O. 2014. Persistent $\mathrm{Wnt} / \beta$-catenin signaling determines dorsalization of the postnatal subventricular zone and neural stem cell specification into oligodendrocytes and glutamatergic neurons. Stem Cells 32, 1301-1312.

Bao H., Asrican B., Li W., Gu B., Wen Z., Lim S.-A., Haniff I., Ramakrishnan C., Deisseroth K., Philpot B., Song J. 2017. Long-range GABAergic inputs regulate neural stem cell quiescence and control adult hippocampal neurogenesis. Cell Stem Cell 21, 604617.

Barkho B.Z., Zhao, X. 2011. Adult neural stem cells: response to stroke injury and potential for therapeutic applications. Curr. Stem Cell Res. Ther. 6, 327-338.

Basak O., Giachino C., Fiorini E., Macdonald H.R., Taylor V. 2012. Neurogenic subventricular zone stem/progenitor cells are Notch1-dependent in their active but not quiescent state. J. Neurosci. 32, 56545666.

Beattie R., Hippenmeyer S. 2017. Mechanisms of radial glia progenitor cell lineage progression. FEBS Lett. 591, 3993-4008.

Bengoa-Vergniory N., Kypta R.M. 2015. Canonical and noncanonical Wnt signaling in neural stem/progenitor cells. Cell. Mol. Life Sci. 72, 4157-4172.

Berg D.A., Bond A.M., Ming G.L., Song H. 2018. Radial glial cells in the adult dentate gyrus: what are they and where do they come from? F1000Research. 7, 277. https://doi.org/10.12688/f1000research.12684.1

Berg D.A., Yoon K., Will B., Xiao A.Y., Kim N.S., Christian K.M., Song H., Ming G.L. 2015. Tbr2expressing intermediate progenitor cells in the adult mouse hippocampus are unipotent neuronal precursors 
with limited amplification capacity under homeostasis. Front Biol. 10, 262-271.

Bhattarai P., Cosacak M.I., Mashkaryan V., Demir S., Popova S.D., Govindarajan N., Brandt K., Zhang Y., Chang W., Ampatzis K., Kizil C. 2020. Neuron-glia interaction through Serotonin-BDNF-NGFR axis enables regenerative neurogenesis in Alzheimer's model of adult zebrafish brain. PLoS Biol. 18, e3000585.

https://doi.org/10.1371/journal.pbio.3000585

Binan L., Tendey C., De Crescenzo G., El Ayoubi R., Ajji A., Jolicoeur M. 2014. Differentiation of neuronal stem cells into motor neurons using electrospun polyL-lactic acid/gelatin scaffold. Biomaterials. 35, 664674.

Bonaguidi M.A., Wheeler M.A., Shapiro J.S., Stadel R.P., Sun G.J., Ming G.L., Song H. 2011. In vivo clonal analysis reveals self-renewing and multipotent adult neural stem cell characteristics. Cell 145, 1142 1155 .

Bosch M., Pineda J.R., Suñol C., Petriz J., Cattaneo E., Alberch J., Canals J.M. 2004. Induction of GABAergic phenotype in a neural stem cell line for transplantation in an excitotoxic model of Huntington's disease. Exp. Neurol. 190, 42-58.

Boschian C., Messina A., Bozza A., Castellini M.E., Provenzano G., Bozzi Y., Casarosa S. 2018. Impaired neuronal differentiation of neural stem cells lacking the Engrailed-2 Gene. Neuroscience 386, 137-149.

Bowman A.N., van Amerongen R., Palmer T.D., Nusse R. 2013. Line- age tracing with Axin2 reveals distinct developmental and adult populations of Wnt/bcatenin-responsive neural stem cells. Proc. Natl. Acad. Sci. U.S.A. 110, 7324-7329.

Bracko O., Singer T., Aigner S., Knobloch M., Winner B., Ray J., Clemenson G.D.J., Suh H., CouillardDespres S., Aigner L., Gage F.H., Jessberger S. 2012. Gene expression profiling of neural stem cells and their neuronal progeny reveals IGF2 as a regulator of adult hippocampal neurogenesis. J. Neurosci. 32, 3376-3387.

Braunschweig L., Meyer A.K., Wagenführ L., Storch A. 2015. Oxygen regulates proliferation of neural stem cells through Wnt $/ \beta$-catenin signalling. Mol. Cell. Neurosci. 67, 84-92.

Burns J.L., Hassan A.B. 2001. Cell survival and proliferation are modified by insulin-like growth factor 2 between days 9 and 10 of mouse gestation. Development. 128, 3819-3830.

Cahoy J., Emery B., Kaushal A., Foo L., Zamanian J., Christopherson K., Xing Y., Lubischer J., Krieg P., Krupenko S., Thompson W., Barres B. 2008. A transcriptome database for astrocytes, neurons, and oligodendrocytes: A new resource for understanding brain development and function. J. Neurosci. 28, 264278.

Cai M., Zhou Y., Zhou B., Lou S. 2014. Hypoxic conditioned medium from rat cerebral cortical cells enhances the proliferation and differentiation of neural stem cells mainly through $\mathrm{PI} 3-\mathrm{K} /$ Akt pathways. PloS One. 9, e111938.

Campanelli J.T., Sandrock R.W., Wheatley W., Xue H., Zheng J., Liang F., Chesnut J.D., Zhan M., Rao M.S., Liu Y. 2008. Expression profiling of human glial precursors. BMC Dev. Biol. 8, 102. https://doi.org/10.1186/1471-213X-8-102

Cao S.Y., Hu Y., Chen C., Yuan F., Xu M., Li Q., Fang K.H., Chen Y., Liu Y. 2017. Enhanced derivation of human pluripotent stem cell-derived cortical glutamatergic neurons by a small molecule. Sci. Rep. 7, 3282. https://doi.org/10.1038/s41598-017-03519-w

Carcagno A.L., Di Bella D.J., Goulding M., Guillemot F., Lanuza G.M. 2014. Neurogenin3 restricts serotonergic neuron differentiation to the hindbrain. J. Neurosci. 34, 15223-15233.

Cattaneo A., Calissano P. 2012. Nerve growth factor and Alzheimer's disease: New facts for an old hypothesis. Mol. Neurobiol. 46, 588-604.

Chavali M., Klingener M., Kokkosis A.G., Garkun Y., Felong S., Maffei A., Aguirre A. 2018. Non-canonical Wnt signaling regulates neural stem cell quiescence during homeostasis and after demyelination. Nat. Commun. 9, 36. https://doi.org/10.1038/s41467-01702440-0

Chen C., Yang Y., Yao Y. 2019. HBO promotes the differentiation of neural stem cells via interactions between the Wnt3/ $\beta$-catenin and BMP2 signaling pathways. Cell Transplant. 28, 1686-1699.

Chirivella L., Kirstein M., Ferrón S.R., Domingo-Muelas A., Durupt F.C., Acosta-Umanzor C., Cano-Jaimez M., Pérez-Sánchez F., Barbacid M., Ortega S., Burks D.J., Fariñas I. 2017. Cyclin-dependent kinase 4 regulates adult neural stem cell proliferation and differentiation in response to insulin. Stem Cells. 35, 2403-2416.

Ciccolini F., Collins T.J., Sudhoelter J., Lipp P., Berridge M.J., Bootman M.D. 2003. Local and global spontaneous calcium events regulate neurite outgrowth and onset of GABAergic phenotype during neural precursor differentiation. J. Neurosci. 23, 103111.

Cochard L.M., Levros L.-C.J., Joppé S.E., Pratesi F., Aumont A., Fernandes, K.J.L. 2021. Manipulation of EGFR-induced signaling for the recruitment of quiescent neural stem cells in the adult mouse forebrain. Front. Neurosci. 15, 621076. https://doi.org/10.3389/fnins.2021.621076

Codega P., Silva-Vargas V., Paul A., Maldonado-Soto A.R., DeLeo A.M., Pastrana E., Doetsch F. 2014. Prospective identification and purification of quiescent adult neural stem cells from their in vivo niche. Neuron. 82, 545-559.

Daadi M. M. 2019. Differentiation of neural stem cells derived from induced pluripotent stem cells into dopaminergic neurons. Methods Mol. Biol. 1919, 8996. 
Darabi S., Tiraihi T., Delshad A., Sadeghizadeh M., Taheri T., Hassoun H.K. 2017. Creatine enhances transdifferentiation of bone marrow stromal cellderived neural stem cell into GABAergic neuron-like cells characterized with differential gene expression. Mol. Neurobiol. 54, 1978-1991.

Darvishi M., Tiraihi T., Mesbah-Namin S.A., Delshad A., Taheri T. 2017. Motor neuron transdifferentiation of neural stem cell from adipose-derived stem cell characterized by differential gene expression. Cell. Mol. Neurobiol. 37, 275-289.

Delgado A.C., Ferrón S.R., Vicente D., Porlan E., PerezVillalba A., Trujillo C.M., D'Ocón P., Fariñas I. 2014. Endothelial NT-3 delivered by vasculature and CSF promotes quiescence of subependymal neural stem cells through nitric oxide induction. Neuron. 83, 572585.

Dihné M., Bernreuther C., Sibbe M., Paulus W., Schachner M. 2003. A new role for the cell adhesion molecule L1 in neural precursor cell proliferation, differentiation, and transmitter-specific subtype generation. J. Neurosci. 23, 6638-6650.

Dindler A., Blaabjerg M., Kamand M., Bogetofte H., Meyer M. 2018. Activation of group ii metabotropic glutamate receptors increases proliferation but does not influence neuronal differentiation of a human neural stem cell line. Basic Clin. Pharmacol. Toxicol. 122, 367-372.

Ding W.Y., Huang J., Wang H. 2020. Waking up quiescent neural stem cells: Molecular mechanisms and implications in neurodevelopmental disorders. PLoS Genet. 16, e1008653.

Doetsch F., Caillé I., Lim D.A., García-Verdugo J.M., Alvarez-Buylla A. 1999. Subventricular zone astrocytes are neural stem cells in the adult mammalian brain. Cell 97, 703-716.

Donega V., Burm S.M., van Strien M.E., van Bodegraven E.J., Paliukhovich I., Geut H., van de Berg W. D.J., Li K.W., Smit A.B., Basak O., Hol E.M. 2019. Transcriptome and proteome profiling of neural stem cells from the human subventricular zone in Parkinson's disease. Acta Neuropathol. Commun. 7, 84. https://doi.org/10.1186/s40478-019-0736-0

Dong J., Pan Y.B., Wu X.R., He L.N., Liu X.D., Feng D.F., Xu T.L., Sun S., Xu N.J. 2019. A neuronal molecular switch through cell-cell contact that regulates quiescent neural stem cells. Sci. Adv. 5, eaav4416. https://doi.org/10.1126/sciadv.aav4416

Draijer, S., Chaves, I., Hoekman, M.F.M. 2019. The circadian clock in adult neural stem cell maintenance. Progress in Neurobiology. 173, 41-53.

Dulken B.W., Leeman D.S., Boutet S.C., Hebestreit K., Brunet A. 2017. Single-cell transcriptomic analysis defines heterogeneity and transcriptional dynamics in the adult neural stem cell lineage. Cell Rep. 18, 777790.

Dumitru I., Neitz A., Alfonso J., Monyer H. 2017. Diazepam binding inhibitor promotes stem cell expansion controlling environment-dependent neurogenesis. Neuron. 94, 125-137.

Ehm O., Göritz C., Covic M., Schäffner I., Schwarz T.J., Karaca E., Kempkes B., Kremmer E., Pfrieger F. W., Espinosa L., Bigas A., Giachino C., Taylor V., Frisén J., Lie D.C. 2010. RBPJkappa-dependent signaling is essential for long-term maintenance of neural stem cells in the adult hippocampus. J. Neurosci. 30, 13794-13807.

Elmlinger M.W., Deininger M.H., Schuett B.S., Meyermann R., Duffner F., Grote E.H., Ranke M.B. 2001. In vivo expression of insulin-like growth factorbinding protein-2 in human gliomas increases with the tumor grade. Endocrinology 142, 1652-1658.

Engler A., Rolando C., Giachino C., Saotome I., Erni A., Brien C., Zhang R., Zimber-Strobl U., Radtke F., Artavanis-Tsakonas S., Louvi A., Taylor V. 2018. Notch2 signaling maintains NSC quiescence in the murine ventricular-subventricular zone. Cell Rep. 22, 992-1002.

Erichsen J.L., Blaabjerg M., Bogetofte H., Serrano A.M., Meyer M. 2015. Group I metabotropic glutamate receptors: a potential target for regulation of proliferation and differentiation of an immortalized human neural stem cell line. Basic Clin. Pharmacol. Toxicol. 116, 329-336.

Fabel K., Kempermann G. 2008. Physical activity and the regulation of neurogenesis in the adult and aging brain. Neuromolecular Med. 10, 59-66.

Fang C.X., Yang X., Sreejayan N., Ren J. 2007. Acetaldehyde promotes rapamycin-dependent activation of $\mathrm{p} 70(\mathrm{~S} 6 \mathrm{~K})$ and glucose uptake despite inhibition of Akt and mTOR in dopaminergic SHSY5Y human neuroblastoma cells. Exp. Neurol. 203, 196-204.

Favaro R., Valotta M., Ferri A.L. M., Latorre E., Mariani J., Giachino C., Lancini C., Tosetti V., Ottolenghi S., Taylor V., Nicolis S.K. 2009. Hippocampal development and neural stem cell maintenance require Sox2-dependent regulation of Shh. Nat. Neurosci. 12, $1248-1256$.

Gabbouj S., Ryhänen S., Marttinen M., Wittrahm R., Takalo M., Kemppainen S., Martiskainen H., Tanila H., Haapasalo A., Hiltunen M., Natunen T. 2019. Altered insulin signaling in Alzheimer's disease brain - special emphasis on PI3K-Akt pathway. Front. Neurosci. 13 ,

629. https://doi.org/10.3389/fnins.2019.00629

Giachino C., Barz M., Tchorz J.S., Tome M., Gassmann M., Bischofberger J., Bettler B., Taylor V. 2014. GABA suppresses neurogenesis in the adult hippocampus through $\mathrm{GABA}_{\mathrm{B}}$ receptors. Development. 141, 83-90.

Gil-Ranedo J., Gonzaga E., Jaworek K.J., Berger C., Bossing T., Barros C.S. 2019. STRIPAK members orchestrate hippo and insulin receptor signaling to promote neural stem cell reactivation. Cell Rep. 27, 2921-2933. 
Gómez-Gaviro M.V., Scott C.E., Sesay A.K., Matheu A., Booth S., Galichet C., Lovell-Badge R. 2012. Betacellulin promotes cell proliferation in the neural stem cell niche and stimulates neurogenesis. Proc. Natl. Acad. Sci. U.S.A. 109, 1317-1322.

Graham V., Khudyakov J., Ellis P., Pevny L. 2003. SOX2 functions to maintain neural progenitor identity. Neuron. 39, 749-765.

Herrick D.B., Guo Z., Jang W., Schnittke N., Schwob J.E. 2018. Canonical Notch signaling directs the fate of differentiating neurocompetent progenitors in the mammalian olfactory epithelium. J. Neurosci. 38, 5022-5037.

Herrick D.B., Lin B., Peterson J., Schnittke N., Schwob J.E. 2017. Notch1 maintains dormancy of olfactory horizontal basal cells, a reserve neural stem cell. Proc. Natl. Acad. Sci. U.S.A. 114, 5589-5598.

Hers I., Vincent E.E., Tavaré J.M. 2011. Akt signalling in health and disease. Cell. Signal. 23, 1515-1527.

Hodge R.D., Kahoud R.J., Hevner R.F. 2012. Transcriptional control of glutamatergic differentiation during adult neurogenesis. Cell. Mol. Life Sci. 69, 2125-2134.

Hodge R.D., Kowalczyk T.D., Wolf S.A., Encinas J.M., Rippey C., Enikolopov G., Kempermann G., Hevner R.F. 2008. Intermediate progenitors in adult hippocampal neurogenesis: Tbr2 expression and coordinate regulation of neuronal output. J. Neurosci. 28, 3707-3717.

$\mathrm{Hu}$ Z., Gajavelli S., Spurlock M.S., Mahavadi A., Quesada L.S., Gajavelli G.R., Andreoni C.B., Di L., Janecki J., Lee S.W., Rivera K.N., Shear D.A., Bullock R.M. 2020. Human neural stem cell transplant location-dependent neuroprotection and motor deficit amelioration in rats with penetrating traumatic brain injury. J. Trauma Acute Care Surg. $88,477-485$.

Huang J., Wang H. 2018. Hsp83/Hsp90 physically associates with insulin receptor to promote neural stem cell reactivation. Stem Cell Rep. 11, 883-896.

Hwang I., Hahm S.C., Choi K.A., Park S.H., Jeong H., Yea J.H., Kim J., Hong S. 2016. Intrathecal transplantation of embryonic stem cell-derived spinal GABAergic neural precursor cells attenuates neuropathic pain in a spinal cord injury rat model. Cell Transplant. 25, 593-607.

Hynes M., Rosenthal A. 1999. Specification of dopaminergic and serotonergic neurons in the vertebrate CNS. Curr. Opin. Neurobiol. 9, 26-36.

Imayoshi I., Sakamoto M., Yamaguchi M., Mor K., Kageyama R. 2010. Essential roles of Notch signaling in maintenance of neural stem cells in developing and adult brains. J. Neurosci. 30, 3489-3498.

Jang M.H., Bonaguidi M.A., Kitabatake Y., Sun J., Song J., Kang E., Jun H., Zhong C., Su Y., Guo J.U., Wang M.X., Sailor K.A., Kim J.Y., Gao Y., Christian K.M., Ming G., Song H. 2013. Secreted frizzled-related protein 3 regulates activity-dependent adult hippocampal neurogenesis. Cell Stem Cell. 12, 215223.

Jansch C., Ziegler G.C., Forero A., Gredy S., Wäldchen S., Vitale M.R., Svirin E., Zöller J.E.M., Waider J., Günther K., Edenhofer F., Sauer M., Wischmeyer E., Lesch K.-P. 2021. Serotonin-specific neurons differentiated from human iPSCs form distinct subtypes with synaptic protein assembly. J. Neural Transm. Vienna. 128, 225-241.

Jeon S.J., Kim J.W., Kim K.C., Han S.M., Go H.S., Seo J.E., Choi C.S., Ryu J.H., Shin C.Y., Song M.R. 2014. Translational regulation of NeuroD1 expression by FMRP: involvement in glutamatergic neuronal differentiation of cultured rat primary neural progenitor cells. Cell. Mol. Neurobiol. 34, 297-305.

Jha B. S., Rao M., Malik N. 2015. Motor neuron differentiation from pluripotent stem cells and other intermediate proliferative precursors that can be discriminated by lineage specific reporters. Stem Cell Rev. Rep. 11, 194-204.

Jiao S., Liu Y., Yao Y., Teng J. 2018. miR-124 promotes proliferation and neural differentiation of neural stem cells through targeting DACT 1 and activating Wnt $/ \beta$ catenin pathways. Mol. Cell Biochem. 449, 305-314.

Jordan P.M., Ojeda L.D., Thonhoff J.R., Gao J., Boehning D., Yu Y., Wu P. 2009. Generation of spinal motor neurons from human fetal brain-derived neural stem cells: Role of basic fibroblast growth factor. J. Neurosci. Res. 87, 318-332.

Kabos P., Kabosova A., Neuman T. 2002. Blocking HES1 expression initiates GABAergic differentiation and induces the expression of p21CIP1/WAF1 in human neural stem cells. J. Biol. Chem. 277, 87638766.

Kageyama R., Ohtsuka T., Kobayashi T. 2007. The Hes gene family: repressors and oscillators that orchestrate embryogenesis. Development. 134, 1243-1251.

Kaise T., Kageyama R. 2021. Hes1 oscillation frequency correlates with activation of neural stem cells. Gene Expr. Patterns. 40, 119170. https://doi.org/10.1016/j.gep.2021.119170

Kang X., Xu H., Teng S., Zhang X., Deng Z., Zhou L., Zuo P., Liu B., Liu B., Wu Q., Wang L., Hu M., Dou H., Liu W., Zhu F., Li Q., Guo S., Gu J., Lei Q., Lu J., Mu Y., Jin M., Wang S., Jiang W., Liu K., Wang C., Li W., Zhang K., Zhou Z. 2014. Dopamine release from transplanted neural stem cells in Parkinsonian rat striatum in vivo. Proc. Natl. Acad. Sc.i U.S.A. 111, 15804-15809.

Kawai H., Kawaguchi D., Kuebrich B.D., Kitamoto T., Yamaguchi M., Gotoh Y., Furutachi S. 2017. Areaspecific regulation of quiescent neural stem cells by Notch3 in the adult mouse subependymal zone. $J$. Neurosci. 37, 11867 - 11880.

Kim H.S., Jeon I., Noh J.-E., Lee H., Hong K.S., Lee N., Pei Z., Song J. 2020. Intracerebral transplantation of BDNF-overexpressing human neural stem cells (HB1.F3. BDNF) promotes migration, differentiation 
and functional recovery in a rodent model of Huntington's disease. Exp. Neurobiol. 29, 130-137.

Kim K.C., Go H.S., Bak H.R., Choi C.S., Choi I., Kim P., Han S.-H., Han S.M., Shin C.Y., Ko K. H. 2010. Prenatal exposure of ethanol induces increased glutamatergic neuronal differentiation of neural progenitor cells. J. Biomed. Sci. 17, 85. https://doi.org/10.1186/1423-0127-17-85

Kobayashi T., Piao W., Takamura T., Kori H., Miyachi H., Kitano S., Iwamoto Y., Yamada M., Imayoshi I., Shioda S., Ballabio A., Kageyama R. 2019. Enhanced lysosomal degradation maintains the quiescent state of neural stem cells. Nat. Commun. 10, 5446. https://doi.org/10.1038/s41467-019-13203-4

Kuwabara T., Hsieh J., Muotri A., Yeo G., Warashina M., Lie D.C., Moore L., Nakashima K., Asashima M., Gage F.H. 2009. Wnt-mediated activation of NeuroD1 and retro-elements during adult neurogenesis. Nat. Neurosci. 12, 1097-1105.

Le Belle J.E., Orozco N.M., Paucar A.A., Saxe J.P., Mottahedeh J., Pyle A.D., Wu H., Kornblum H.I. 2011. Proliferative neural stem cells have high endogenous ROS levels that regulate self-renewal and neurogenesis in a PI3K/Akt-dependant manner. Cell Stem Cell. 8, 59-71.

Lee J.C., Mayer-Proschel M., Rao M.S. 2000. Gliogenesis in the central nervous system. Glia. 30, 105-121.

Lee J.E., Lim M.S., Park J.H., Park C.H., Koh H.C. 2016a. S6K Promotes dopaminergic neuronal differentiation through PI3K/Akt/mTOR-dependent signaling pathways in human neural stem cells. Mol. Neurobiol. 53, 3771-3782.

Lee J.E., Lim M.S., Park J.H., Park C.H., Koh H.C. 2016b. PTEN promotes dopaminergic neuronal differentiation through regulation of ERK-dependent inhibition of S6K signaling in human neural stem cells. Stem. Cells. Transl. Med. 5, 1319-1329.

Leeman D.S., Hebestreit K., Ruetz T., Webb A.E., McKay A., Pollina E.A., Dulken B.W., Zhao X., Yeo R.W., Ho T.T., Mahmoudi S., Devarajan K., Passegué E., Rando T.A., Frydman J., Brunet A. 2018. Lysosome activation clears aggregates and enhances quiescent neural stem cell activation during aging. Science. 359, 1277 - 1283.

Li F., Wei H., Li H., Li X., Hu C., Zhang J., Deng Y., Liao X. 2019. miR-26a prevents neural stem cells from apoptosis via $\beta$-catenin signaling pathway in cardiac arrest-induced brain damage. Biosci. Rep. 39, BSR20181635. https://doi.org/10.1042/BSR20181635

Li L., Harms K.M., Ventura P.B., Lagace D.C., Eisch A.J., Cunningham L.A. 2010. Focal cerebral ischemia induces a multilineage cytogenic response from adult subventricular zone that is predominantly gliogenic. Glia. 58, 1610-1619.

Li Q., Wang P., Huang C., Chen B., Liu J., Zhao M., Zhao J. 2019. N-Acetyl serotonin protects neural progenitor cells against oxidative stress-induced apoptosis and improves neurogenesis in adult mouse hippocampus following traumatic brain injury. J. Mol. Neurosci. 67, 574-588.

Lichtenwalner R.J., Forbes M.E., Bennett S.A., Lynch C.D., Sonntag W. E., Riddle D.R. 2001. Intracerebroventricular infusion of insulin-like growth factor-I ameliorates the age-related decline in hippocampal neurogenesis. Neuroscience. 107, 603613.

Lie D.C., Colamarino S.A., Song H.J., De' sire' L., Mira H., Consiglio A., Lein E.S., Jessberger S., Lansford H., Dearie A.R., Gage F.H. 2005. Wnt signaling regulates adult hippocampal neurogenesis. Nature. 437, 1370-1375.

Lin K., Liu B., Lim S.-L., Fu X., Sze S.C.-W., Yung K.K.-L., Zhang S. 2020. 20(S)-protopanaxadiol promotes the migration, proliferation, and differentiation of neural stem cells by targeting GSK$3 \beta$ in the Wnt/GSK-3 $\beta / \beta$-catenin pathway. J. Ginseng Res. 44, 475-482.

Lin K., Sze S.C.W., Liu B., Zhang Z., Zhang Z., Zhu P., Wang Y., Deng Q., Yung K.K.L., Zhang S. 2021. 20(S)-protopanaxadiol and oleanolic acid ameliorate cognitive deficits in APP/PS1 transgenic mice by enhancing hippocampal neurogenesis. J. Ginseng Res. 45, 325-333.

Lin L., Yuan J., Sander B., Golas M.M. 2015. In vitro differentiation of human neural progenitor cells into striatal GABAergic neurons. Stem. Cells. Transl. Med. 4, 775-788.

Lin Y., Jiang T., Zhou K., Xu L., Chen B., Li G., Qiu X., Jiang T., Zhang W., Song S.W. 2009. Plasma IGFBP2 levels predict clinical outcomes of patients with high-grade gliomas. Neuro Oncol. 11, 468-476.

Liu C.X., Xu X., Chen X.L., Yang P.B., Zhang J.S., Liu Y. 2015. Glutamate promotes neural stem cell proliferation by increasing the expression of vascular endothelial growth factor of astrocytes in vitro. Cell. Mol. Biol. 61, 75-84.

Liu M., Pleasure S.J., Collins A.E., Noebels J.L., Naya F.J., Tsai M.J., Lowenstein D.H. 2000. Loss of BETA2/NeuroD leads to malformation of the dentate gyrus and epilepsy. Proc. Natl. Acad. Sci. U.S.A. 97, 865-870.

Liu Q., Li Y., Zhou L., Li Y., Xu P., Liu X., Lv Q., Li J., Guo H., Cai H., Sun R., Liu X. 2018. GRP78 promotes neural stem cell antiapoptosis and survival in response to oxygen-glucose deprivation (OGD)/reoxygenation through PI3K/Akt, ERK1/2,

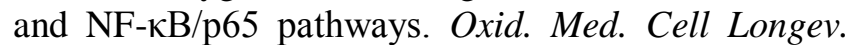
2018, 3541807. https://doi.org/10.1155/2018/3541807

Llorens-Bobadilla E., Zhao S., Baser A., Saiz-Castro G., Zwadlo K., Martin-Villalba A. 2015. Single-cell transcriptomics reveals a population of dormant neural stem cells that become activated upon brain injury. Cell Stem Cell. 17, 329-340.

Lu J., Zhong X., Liu H., Hao L., Huang C.T.L., Sherafat M.A., Jones J., Ayala M., Li L., Zhang S.C. 2016. 
Generation of serotonin neurons from human pluripotent stem cells. Nat. Biotechnol. 34, 89-94.

Lu Q., Zhu H., Liu X., Tang C. 2020. Icariin sustains the proliferation and differentiation of $\mathrm{A} \beta$ (25-35)-treated hippocampal neural stem cells via the BDNF-TrkBERK/Akt signaling pathway. Neurol. Res. 42, 936945.

Lu Z., Xu S. 2006. ERK1/2 MAP kinases in cell survival and apoptosis. IUBMB Life 58, 621-631.

MacDonald B.T., Tamai K., He X. 2009. Wnt/betacatenin signaling: components, mechanisms, and diseases. Dev. Cell. 17, 9-26.

Maisano X., Litvina E., Tagliatela S., Aaron G.B., Grabel L.B., Naegele, J.R. 2012. Differentiation and functional incorporation of embryonic stem cellderived GABAergic interneurons in the dentate gyrus of mice with temporal lobe epilepsy. J. Neurosci. 32, 46-61.

Marqués-Torrejón M.Á., Williams C.A.C., Southgate B., Alfazema N., Clements M.P., Garcia-Diaz C., Blin C., Arranz-Emparan N., Fraser J., Gammoh N., Parrinello S., Pollard S.M. 2021. LRIG1 is a gatekeeper to exit from quiescence in adult neural stem cells. Nat. Commun. 12, 2594. https://doi.org/10.1038/s41467021-22813-w

Martins-Macedo J., Lepore A.C., Domingues H.S., Salgado A.J., Gomes E.D., Pinto L., 2021. Glial restricted precursor cells in central nervous system disorders: Current applications and future perspectives. Glia 69, 513-531.

Mase S., Shitamukai A., Wu Q., Morimoto M., Gridley T., Matsuzaki F. 2020. Notch1 and Notch2 collaboratively maintain radial glial cells in mouse neurogenesis. Neurol. Res. S0168-0102(20)30492-2. https://doi.org/10.1016/j.neures.2020.11.007

Massirer K.B., Carromeu C., Griesi-Oliveira K., Muotri A.R. 2011. Maintenance and differentiation of neural stem cells. WIREs Syst. Biol. Med. 3, 107-114.

Matsui T. K., Mori E. 2018. Microglia support neural stem cell maintenance and growth. Biochem. Biophys. Res. Commun. 503, 1880-1884.

Mazzini L., Gelati M., Profico D.C., Sgaravizzi G., Projetti Pensi M., Muzi G., Ricciolini C., Rota Nodari L., Carletti S., Giorgi C., Spera C., Domenico F., Bersano E., Petruzzelli F., Cisari C., Maglione A., Sarnelli M.F., Stecco A., Querin G., Vescovi A.L. 2015. Human neural stem cell transplantation in ALS: initial results from a phase I trial. J. Transl. Med. 13, 17. https://doi.org/10.1186/s12967-014-0371-2

McCubrey J.A., Steelman L.S., Chappell W.H., Abrams S.L., Wong E.W., Chang F., Lehmann B., Terrian D.M., Milella M., Tafuri A., Stivala F., Libra M., Basecke J., Evangelisti C., Martelli A.M., Franklin R.A. 2007. Roles of the Raf/MEK/ERK pathway in cell growth, malignant transformation and drug resistance. Biochim. Biophys. Acta. 1773, 1263-1284.

Mendonça L.S., Nóbrega C., Hirai H., Kaspar B.K., Pereira de Almeida L. 2015. Transplantation of cerebellar neural stem cells improves motor coordination and neuropathology in Machado-Joseph disease mice. Brain. 138, 320-335.

Mi H., Barres B.A. 1999. Purification and characterization of astrocyte precursor cells in the developing rat optic nerve. J. Neurosci. 19, 10491061.

Michalski D., Keck A.L., Grosche J., Martens H., Härtig W. 2018. Immunosignals of oligodendrocyte markers and myelin-associated proteins are critically affected after experimental stroke in wild-type and Alzheimer modeling mice of different ages. Front. Cell. Neurosci. $12, \quad 23$. https://www.frontiersin.org/article/10.3389/fncel.2018 .00023

Mira H., Andreu Z., Suh H., Lie D.C., Jessberger S., Consiglio A., San Emeterio J., Hortigüela R., Marqués-Torrejón M.A., Nakashima K., Colak D., Götz M., Fariñas I., Gage F.H. 2010. Signaling through BMPR-IA regulates quiescence and longterm activity of neural stem cells in the adult hippocampus. Cell Stem Cell. 7, 78-89.

Moore L.M., Holme K.M., Smith S.M., Wu Y., Tchougounova E., Uhrbom L., Sawaya R., Bruner J.M., Fuller G.N., Zhang W. 2009. IGFBP2 is a candidate biomarker for Ink4a-Arf status and a therapeutic target for high-grade gliomas. Proc. Natl. Acad. Sci. U.S.A. 106, 16675-16679.

Morrow C.S., Porter T.J., Xu N., Arndt Z.P., Ako-Asare K., Heo H.J., Thompson E.A.N., Moore D.L. 2020. Vimentin coordinates protein turnover at the aggresome during neural stem cell quiescence exit. Cell Stem Cell. 26, 558-568.

Moss J., Toni N. 2013. A circuit-based gatekeeper for adult neural stem cell proliferation: Parvalbuminexpressing interneurons of the dentate gyrus control the activation and proliferation of quiescent adult neural stem cells. Bioessays. 35, 28-33.

Nakaji-Hirabayashi T., Fujimoto K., Yoshikawa C., Kitano H. 2019. Functional surfaces for efficient differentiation of neural stem/progenitor cells into dopaminergic neurons. J. Biomed. Mater. Res. A. 107, 860-871.

Natarajan R., Singal V., Benes R., Gao J., Chan H., Chen H., Yu Y., Zhou J., Wu P. 2014. STAT3 modulation to enhance motor neuron differentiation in human neural stem cells. PloS One. 9, e100405. https://doi.org/10.1371/journal.pone.0100405

Niehrs C. 2012. The complex world of WNT receptor signalling. Nat. Rev. Mol.Cell Biol. 13, 767-79.

Nikouei K., Muñoz-Manchado A.B., Hjerling-Leffler J. 2016. BCL11B/CTIP2 is highly expressed in GABAergic interneurons of the mouse somatosensory cortex. J. Chem. Neuroanat. 71, 1-5.

O’Brien L.C., Keeney P.M., Bennett J.P.J. 2015. Differentiation of human neural stem cells into motor neurons stimulates mitochondrial biogenesis and 
decreases glycolytic flux. Stem Cells Dev. 24, 1984 1994.

Ojeda L., Gao J., Hooten K.G., Wang E., Thonhoff J.R., Dunn T.J., Gao T., Wu P. 2011. Critical role of $\mathrm{PI} 3 \mathrm{~K} / \mathrm{Akt} / \mathrm{GSK} 3 \beta$ in motoneuron specification from human neural stem cells in response to FGF2 and EGF. PloS One. 6, e23414. https://doi.org/10.1371/journal.pone.0023414

Otsuki L., Brand A. H. 2020. Quiescent neural stem cells for brain repair and regeneration: Lessons from model systems. Trends Neurosci. 43, 213-226.

Otsuki L., Brand A.H. 2018. Cell cycle heterogeneity directs the timing of neural stem cell activation from quiescence. Science. 360, 99-102.

Ottone C., Krusche B., Whitby A., Clements M., Quadrato G., Pitulescu M.E., Adams R.H., Parrinello S. 2014. Direct cell-cell contact with the vascular niche maintains quiescent neural stem cells. Nat. Cell Biol. 16, 1045-1056.

Paez-Gonzalez P., Asrican B., Rodriguez E., Kuo C.T. 2014. Identification of distinct ChAT + neurons and activity-dependent control of postnatal SVZ neurogenesis. Nat. Neurosci. 17, 934-942.

Qi C., Zhang J., Chen X., Wan J., Wang J., Zhang P., Liu Y. 2017. Hypoxia stimulates neural stem cell proliferation by increasing HIF-1 $\alpha$ expression and activating Wnt $/ \beta$-catenin signaling. Cell. Mol. Biol. 63, 12-19.

Qu Q., Sun G., Li W., Yang S., Ye P., Zhao C., Yu R.T., Gage F.H., Evans R.M., Shi Y. 2010. Orphan nuclear receptor TLX activates $\mathrm{Wnt} / \beta$-catenin signalling to stimulate neural stem cell proliferation and selfrenewal. Nat. Cell Biol. 12, 31-40.

Qu Q., Sun G., Murai K., Ye P., Li W., Asuelime G., Cheung Y.T., Shi Y. 2013. Wnt7a regulates multiple steps of neurogenesis. Mol. Cell. Biol. 33, 2551-2559

Raff M.C., Abney E.R., Cohen J., Lindsay R., Noble M. 1983. Two types of astrocytes in cultures of developing rat white matter: differences in morphology, surface gangliosides, and growth characteristics. J. Neurosci. 3, $1289-1300$.

Ramos-Moreno T., Castillo C.G., Martínez-Serrano A. 2012. Long term behavioural effects of functional dopaminergic neurons generated from human neural stem cells in the rat 6-OH-DA Parkinson's disease model. Effects of the forced expression of BCL-X(L). Behav. Brain. Res. 232, 225-232.

Ren-Patterson R. F., Kim D.-K., Zheng X., Sherrill S., Huang S.-J., Tolliver T., Murphy D.L. 2005. Serotonergic-like progenitor cells propagated from neural stem cells in vitro: survival with SERT protein expression following implantation into brains of mice lacking SERT. FASEB J. 19, 1537-1539.

Riaz S.S., Theofilopoulos S., Jauniaux E., Stern G.M., Bradford H.F. 2004. The differentiation potential of human foetal neuronal progenitor cells in vitro. Brain Res. Dev. Brain Res. 153, 39-51.
Robson J.P., Wagner B., Glitzner E., Heppner F.L., Steinkellner T., Khan D., Petritsch C., Pollak D.D., Sitte H.H., Sibilia M. 2018. Impaired neural stem cell expansion and hypersensitivity to epileptic seizures in mice lacking the EGFR in the brain. FEBS J. 285, 3175-3196.

Rössler R., Boddeke E., Copray S. 2010. Differentiation of non-mesencephalic neural stem cells towards dopaminergic neurons. Neuroscience. 170, 417-428.

Rouaux C., Arlotta P. 2010. Fezf2 directs the differentiation of corticofugal neurons from striatal progenitors in vivo. Nat. Neurosci. 13, 1345-1347.

Rowitch D.H., Lu Q.R., Kessaris N., Richardson W.D. 2002. An "oligarchy" rules neural development. Trends Neurosci. 25, 417-422.

Sagal J., Zhan X., Xu J., Tilghman J., Karuppagounder S.S., Chen L., Dawson V.L., Dawson T.M., Laterra J., Ying M. 2014. Proneural transcription factor Atoh1 drives highly efficient differentiation of human pluripotent stem cells into dopaminergic neurons. Stem cells Transl. Med. 3, 888-898.

Salli U., Reddy A.P., Salli N., Lu N.Z., Kuo H.C., Pau F.K.Y., Wolf D.P., Bethea C.L. 2004. Serotonin neurons derived from rhesus monkey embryonic stem cells: similarities to CNS serotonin neurons. Exp. Neurol. 188, 351-364.

Sallinen S.L., Sallinen P.K., Haapasalo H.K., Helin H.J., Helen P.T., Schraml P., Kallioniemi O.P., Kononen J. 2000. Identification of differentially expressed genes in human gliomas by DNA microarray and tissue chip techniques. Cancer Res. 60, 6617-6622.

Samarasinghe R.A., Kanuparthi P.S., Timothy Greenamyre J., DeFranco D. B., Di Maio R. 2014. Transient muscarinic and glutamatergic stimulation of neural stem cells triggers acute and persistent changes in differentiation. Neurobiol. Dis. 70, 252-261.

Schuurmans C., Armant O., Nieto M., Stenman J.M., Britz O., Klenin N., Brown C., Langevin L.-M., Seibt J., Tang H., Cunningham J.M., Dyck R., Walsh C., Campbell K., Polleux F., Guillemot F. 2004. Sequential phases of cortical specification involve Neurogenin-dependent and independent pathways. EMBO J. 23, 2892-2902.

Seib D.R.M., Corsini N.S., Ellwanger K., Plaas C., Mateos A., Pitzer C., Niehrs C., Celikel T., MartinVillalba A. 2013. Loss of Dickkopf-1 restores neurogenesis in old age and counteracts cognitive decline. Cell Stem Cell. 12, 204-214.

Shao Z., Luo Q., Liu D., Mi Y., Zhang P., Ju G. 2011. Induced differentiation of neural stem cells of astrocytic origin to motor neurons in the rat. Stem Cells Dev. 20, 1163-1170.

Shen F., Song C., Liu Y., Zhang J., Wei Song S. 2019. IGFBP2 promotes neural stem cell maintenance and proliferation differentially associated with glioblastoma subtypes. Brain Res. 1704, 174-186.

Shi,Y., Zhao,X., Hsieh,J., Wichterle,H., Impey,S., Banerjee,S., Neveu,P. and Kosik,K.S. 2010. 
MicroRNA regulation of neural stem cells and neurogenesis. J. Neurosci. 30, 14931-14936

Shin J., Berg D.A., Zhu Y., Shin J.Y., Song J., Bonaguidi M.A., Enikolopov G., Nauen D.W., Christian K.M., Ming G., Song H. 2015. Single-cell RNA-seq with waterfall reveals molecular cascades underlying adult neurogenesis. Cell Stem Cell. 17, 360-372.

Shin M.H., Lee E.-G., Lee S.-H., Lee Y.S., Son H. 2002. Neural cell adhesion molecule (NCAM) promotes the differentiation of hippocampal precursor cells to a neuronal lineage, especially to a glutamatergic neural cell type. Exp. Mol. Med. 34, 401-410.

Si Z., Wang X., Kang Y., Wang X., Sun C., Li Y., Xu J., Wu J., Zhang Z., Li L., Peng Y., Li J., Sun C., Hui Y., Gao X. 2020. Heme oxygenase 1 inhibits adult neural stem cells proliferation and survival via modulation of Wnt/ $\beta$-catenin signaling. J. Alzheimers Dis. 76, 623641.

Sierra A., Martín-Suárez S., Valcárcel-Martín R., Pascual-Brazo J., Aelvoet S.-A., Abiega O., Deudero J.J., Brewster A.L., Bernales I., Anderson A.E., Baekelandt V., Maletić-Savatić M., Encinas J.M. 2015. Neuronal hyperactivity accelerates depletion of neural stem cells and impairs hippocampal neurogenesis. Cell Stem Cell. 16, 488-503.

Silva A., Pereira J., Oliveira C. R., Relvas J. B., Rego A.C. 2009. BDNF and extracellular matrix regulate differentiation of mice neurosphere-derived cells into a GABAergic neuronal phenotype. J. Neurosci. Res. 87, 1986-1996.

Solozobova V., Wyvekens N., Pruszak J. 2012. Lessons from the embryonic neural stem cell niche for neural lineage differentiation of pluripotent stem cells. Stem Cell Rev. Reports. 8, 813-829.

Song D., Chen Y., Chen C., Che, L., Cheng O. 2021. $\mathrm{GABA}(\mathrm{B})$ receptor antagonist promotes hippocampal neurogenesis and facilitates cognitive function recovery following acute cerebral ischemia in mice. Stem Cell Res. Ther. 12, 22. https://doi.org/10.1186/s13287-020-02059-X

Song J., Zhong C., Bonaguidi M.A., Sun G.J., Hsu D., Gu Y., Meletis K., Huang Z.J., Ge S., Enikolopov G., Deisseroth K., Luscher B., Christian K.M., Ming G., Song H. 2012. Neuronal circuitry mechanism regulating adult quiescent neural stem-cell fate decision. Nature 489, 150-154.

Song M., Yu S.P., Mohamad O., Cao W., Wei Z.Z., Gu X., Jiang M.Q., Wei L. 2017. Optogenetic stimulation of glutamatergic neuronal activity in the striatum enhances neurogenesis in the subventricular zone of normal and stroke mice. Neurobiol. Dis. 98, 9-24.

Steindler D.A., Okun M.S., Scheffler B. 2012. Stem cell pathologies and neurological disease. Mod. Pathol. 25, 157-162.

Sueda R., Kageyama R. 2020. Regulation of active and quiescent somatic stem cells by Notch signaling. Dev. Growth Differ. 62, 59-66.
Suh H., Consiglio A., Ray J., Sawai T., D’Amour K.A., Gage F.H. 2007. In vivo fate analysis reveals the multipotent and self-renewal capacities of Sox2+ neural stem cells in the adult hippocampus. Cell Stem Cell. 1, 515-528.

Sun J., Bonaguidi M.A., Jun H., Guo J.U., Sun G.J., Will B., Yang Z., Jang M.-H., Song H., Ming G., Christian K.M. 2015. A septo-temporal molecular gradient of sfrp3 in the dentate gyrus differentially regulates quiescent adult hippocampal neural stem cell activation. Mol. Brain. 8, 52. https://doi.org/10.1186/s13041-015-0143-9

Sun L., Han R., Guo F., Chen H., Wang W., Chen Z., Liu W., Sun X., Gao C. 2020. Antagonistic effects of IL17 and Astragaloside IV on cortical neurogenesis and cognitive behaviour after stroke in adult mice through Akt/GSK-3 $\beta$ pathway. Cell Death Discov. 6, 74. https://doi.org/10.1038/s41420-020-00298-8

Sun Y., Liu W.Z., Liu T., Feng X., Yang N., Zhou H.F. 2015. Signaling pathway of $M A P K / E R K$ in cell proliferation, differentiation, migration, senescence and apoptosis. J. Recept. Signal Transduct. Res. 35, 600-604.

Tan X., Zhang L., Zhu H., Qin J., Tian M., Dong C., Li H., Jin G. 2014. Brn4 and TH synergistically promote the differentiation of neural stem cells into dopaminergic neurons. Neurosci. Lett. 571, 23-28.

Tan X.F., Jin G.H., Tian M.L., Qin J.B., Zhang L., Zhu H.X., Li H.M. 2011. The co-transduction of Nurr1 and Brn4 genes induces the differentiation of neural stem cells into dopaminergic neurons. Cell Biol. Int. 35, 1217-1223.

Than-Trong E., Ortica-Gatti S., Mella S., Nepal C., Alunni A., Bally-Cuif L. 2018. Neural stem cell quiescence and stemness are molecularly distinct outputs of the Notch3 signaling cascade in the vertebrate adult brain. Development. 145, dev.161034. https://doi.org/10.1242/dev.161034

Tian R., Guo K., Wu B., Wang H. 2020. Overexpression of Shrm4 promotes proliferation and differentiation of neural stem cells through activation of GABA signaling pathway. Mol. Cell. Biochem. 463, 115-126.

Tiwari S.K., Agarwal S., Seth B., Yadav A., Ray R.S., Mishra V.N., Chaturvedi R.K. 2015. Inhibitory effects of bisphenol-a on neural stem cells proliferation and differentiation in the rat brain are dependent on Wnt/ $\beta$-Catenin pathway. Mol. Neurobiol. 52, 17351757 .

Tong C.K., Chen J., Cebrián-Silla A., Mirzadeh Z., Obernier K., Guinto C.D., Tecott L.H., GarcíaVerdugo J.M., Kriegstein A., Alvarez-Buylla A. 2014. Axonal control of the adult neural stem cell niche. Cell Stem Cell. 14, 500-511.

Urbán N., Blomfield I.M., Guillemot F. 2019. Quiescence of adult mammalian neural stem cells: a highly regulated rest. Neuron. 104, 834-848.

Urbán N., van den Berg D.L.C., Forget A., Andersen J., Demmers J.A.A., Hunt C., Ayrault O., Guillemot F. 
2016. Return to quiescence of mouse neural stem cells by degradation of a proactivation protein. Science 353, 292-295.

Wagner J., Akerud P., Castro D.S., Holm P.C., Canals J.M., Snyder E.Y., Perlmann T., Arenas E. 1999. Induction of a midbrain dopaminergic phenotype in Nurr1-overexpressing neural stem cells by type 1 astrocytes. Nat. Biotechnol. 17, 653-659.

Wang J., Chen T., Shan G. 2017. miR-148b regulates proliferation and differentiation of neural stem cells via $\mathrm{Wnt} / \beta$-catenin signaling in rat ischemic stroke model. Front. Cell. Neurosci. 11, 329. https://doi.org/10.3389/fncel.2017.00329

Wang J., Fu X., Zhang D., Yu L., Li N., Lu Z., Gao Y., Wang M., Liu X., Zhou C., Han W., Yan B., Wang J. 2017. ChAT-positive neurons participate in subventricular zone neurogenesis after middle cerebral artery occlusion in mice. Behav. Brain Res. 316, 145-151.

Wang Y.Z., Plane J.M., Jiang P., Zhou C.J., Deng W. 2011. Concise review: quiescent and active states of endogenous adult neural stem cells: identification and characterization. Stem Cells 29, 907-912.

Wu L.Y., He Y.L., Zhu L.L. 2018. Possible role of PHD inhibitors as hypoxia-mimicking agents in the maintenance of neural stem cells' self-renewal properties. Front. Cell Dev. Biol. 6, 169. https://doi.org/10.3389/fcell.2018.00169

Xing L., Kalebic N., Namba T., Vaid S., Wimberger P., Huttner W.B. 2020. Serotonin receptor 2A activation promotes evolutionarily relevant basal progenitor proliferation in the developing neocortex. Neuron 108, 1113-1129.

Xu K., Liu F., Xu W., Liu J., Che, S., Wu G. 2019. Transplanting GABAergic neurons differentiated from neural stem cells into hippocampus inhibits seizures and epileptiform discharges in pilocarpine-induced temporal lobe epilepsy model. World Neurosurg. 128, $1-11$.

Xue W.S., Wang N., Wang N.Y., Ying Y.F., Xu, G.H. 2019. miR-145 protects the function of neuronal stem cells through targeting MAPK pathway in the treatment of cerebral ischemic stroke rat. Brain. Res. Bull. 144, 28-38.

Yao B., Christian K.M., He C., Jin P., Ming G.L., Song H. 2016. Epigenetic mechanisms in neurogenesis. Nat. Rev. Neurosci. 17, 537-549.

Ye W., Shimamura K., Rubenstein J. L., Hynes M. A., Rosenthal A. 1998. FGF and Shh signals control dopaminergic and serotonergic cell fate in the anterior neural plate. Cell. 93, 755-766.

Yeh C.Y., Asrican B., Moss J., Quintanilla L.J., He T., Mao X., Cassé F., Gebara E., Bao H., Lu W., Toni N., Song J. 2018. Mossy cells control adult neural stem cell quiescence and maintenance through a dynamic balance between direct and indirect pathways. Neuron. 99, 493-510.
Yue Y., Xue Q., Yang J., Li X., Mi Z., Zhao G., Zhang L. 2020. Wnt-activated olfactory ensheathing cells stimulate neural stem cell proliferation and neuronal differentiation. Brain Res. 1735, 146726. https://doi.org/10.1016/j.brainres.2020.146726

Yun D., Lee Y.M., Laughter M.R., Freed C.R., Park D. 2015. Substantial differentiation of human neural stem cells into motor neurons on a biomimetic polyurea. Macromol. Biosci. 15, 1206-1211.

Zelentsova K., Talmi Z., Abboud-Jarrous G., Sapir T., Capucha T., Nassar M., Burstyn-Cohen T. 2017. Protein $\mathrm{S}$ regulates neural stem cell quiescence and neurogenesis. Stem Cells. 35, 679-693.

Zhang J., He L., Yang Z., Li L., Cai W. 2019. Lithium chloride promotes proliferation of neural stem cells in vitro, possibly by triggering the Wnt signaling pathway. Anim. Cells Syst. 23, 32-41.

Zhang J., Jiao J. 2015. Molecular biomarkers for embryonic and adult neural stem cell and neurogenesis. Biomed Res. Int. 2015, 727542. https://doi.org/10.1155/2015/727542

Zhang K., Xu H., Cao L., Li K., Huang Q. 2013. Interleukin-1 $\beta$ inhibits the differentiation of hippocampal neural precursor cells into serotonergic neurons. Brain Res. 1490, 193-201.

Zhang R., Boareto M., Engler A., Louvi A., Giachino C., Iber D., Taylor V. 2019. Id4 downstream of Notch2 maintains neural stem cell quiescence in the adult hippocampus. Cell Rep. 28, 1485-1498.

Zhang S.Q., Lin K.L., Law C.Y., Liu B., Fu X.Q., Tse W.S., Wong S.S.M., Sze S.C.W., Yung K.K.L. 2018. Oleanolic acid enhances neural stem cell migration, proliferation, and differentiation in vitro by inhibiting GSK3 $\beta$ activity. Cell Death Discov. 4, 48. https://doi.org/10.1038/s41420-018-0111-0

Zhang T., Ke W., Zhou X., Qian Y., Feng S., Wang R., Cui G., Tao R., Guo W., Duan Y., Zhang X., Cao X., Shu Y., Yue C., Jing N. 2019. Human neural stem cells reinforce hippocampal synaptic network and rescue cognitive deficits in a mouse model of Alzheimer's disease. Stem Cell Rep. 13, 1022-1037.

Zhang W., Gu G.J., Zhang Q., Liu J.H., Zhang B., Guo Y., Wang M.Y., Gong Q.Y., Xu, J.R. 2017. NSCs promote hippocampal neurogenesis, metabolic changes and synaptogenesis in APP/PS1 transgenic mice. Hippocampus 27, 1250-1263.

Zhang W.-M., Zhang Z.-R., Yang X.-T., Zhang Y.-G., Gao Y.-S. 2018. Overexpression of miR-21 promotes neural stem cell proliferation and neural differentiation via the $\mathrm{Wnt} / \beta$-catenin signaling pathway in vitro. Mol. Med. Rep. 17, 330-335.

Zhang X., Mei Y., He Y., Wang D., Wang J., Wei X., Yang E., Zhou D., Shen H., Peng G., Shu Q., Li X., Luo B., Zhou Y., Sun B. 2021. Ablating adult neural stem cells improves synaptic and cognitive functions in alzheimer models. Stem Cell Reports. 16, 89-105.

Zhang Y., Liu G., Guo T., Liang X.G., Du H., Yang L., Bhaduri A., Li X., Xu Z., Zhang Z., Li Z., He M., 
Tsyporin J., Kriegstein A.R., Rubenstein J.L., Yang Z., Chen B. 2020. Cortical neural stem cell lineage progression is regulated by extrinsic signaling molecule Sonic hedgehog. Cell Rep. 30, 4490-4504.

Zhang Z., Ma Z., Zou W., Guo H., Liu M., Ma Y., Zhang L. 2019. The appropriate marker for astrocytes: Comparing the distribution and expression of three astrocytic markers in different mouse cerebral regions. Biomed Res. Int. 2019, 9605265. https://doi.org/10.1155/2019/9605265

Zhao C., Eisinger B., Gammie S.C. 2013. Characterization of GABAergic neurons in the mouse lateral septum: a double fluorescence in situ hybridization and immunohistochemical study using tyramide signal amplification. PLOS ONE. 8, e73750. https://doi.org/10.1371/journal.pone.0073750

Zhao L., Yan M., Wang X., Xiong G., Wu C., Wang Z., Zhou Z., Chang X. 2018. Modification of Wnt signaling pathway on paraquat-induced inhibition of neural progenitor cell proliferation. Food Chem. Toxicol. 121, 311-325.

Zhao X., Moore D.L. 2018. Neural stem cells: developmental mechanisms and disease modeling. Cell. Tissue. Res. 371, 1-6.

Zhou Z., Dun L., Wei B., Gan Y., Liao Z., Lin X., Lu J., Liu G., Xu H., Lu C., An H. 2020. Musk ketone induces neural stem cell proliferation and differentiation in cerebral ischemia via activation of the PI3K/Akt signaling pathway. Neuroscience. 435, $1-9$.

Zhu Q., Zhang N., Hu N., Jiang R., Lu H., Xuan A., Long D., Chen, Y. 2020. Neural stem cell transplantation improves learning and memory by protecting cholinergic neurons and restoring synaptic impairment in an amyloid precursor protein/presenilin 1 transgenic mouse model of Alzheimer's disease. Mol. Med. Rep. 21, 1172-1180.

Ziegler A.N., Chidambaram S., Forbes B.E., Wood T.L., Levison S.W. 2014. Insulin-like growth factor-II (IGF-II) and IGF-II analogs with enhanced insulin receptor-a binding affinity promote neural stem cell expansion. J. Biol. Chem. 289, 4626-4633.

Ziegler A.N., Levison S.W., Wood T.L. 2015. Insulin and IGF receptor signalling in neural-stem-cell homeostasis. Nat. Rev. Endocrinol. 11, 161-170.

Ziegler A.N., Schneider J.S., Qin M., Tyler W.A., Pintar J.E., Fraidenraich D., Wood T.L., Levison S.W. 2012. IGF-II promotes stemness of neural restricted precursors. Stem Cells. 30, 1265-1276.

Zuccotti A., Le Magueresse C., Chen M., Neitz A., Monyer H. 2014. The transcription factor Fezf2 directs the differentiation of neural stem cells in the subventricular zone toward a cortical phenotype. Proc. Natl. Acad. Sci. U.S.A. 111, 10726-10731. 